\title{
Heterocycle Syntheses with Anionic N-Heterocyclic Carbenes : Ring Transformations of Sydnone Imine Anions
}

\section{Freese, Tyll}

2018-04-17

Freese , T, Luecke , A-L, Namyslo , J C , Nieger , M \& Schmidt , A 2018 , ' Heterocycle Syntheses with Anionic N-Heterocyclic Carbenes : Ring Transformations of Sydnone Imine Anions ' , European Journal of Organic Chemistry , no. 14 , pp. 1646-1654 . https://doi.org/10.1002/ejoc.201800028

http://hdl.handle.net/10138/324828

https://doi.org/10.1002/ejoc.201800028

unspecified

acceptedVersion

Downloaded from Helda, University of Helsinki institutional repository.

This is an electronic reprint of the original article.

This reprint may differ from the original in pagination and typographic detail.

Please cite the original version. 


\title{
Heterocycle syntheses with anionic N-heterocyclic carbenes. Ring transformations of sydnone imine anions
}

\author{
Tyll Freese ${ }^{[a]}$ Ana-Luiza Lücke, ${ }^{[a]}$ Jan C. Namyslo, ${ }^{[a]}$ Martin Nieger ${ }^{[b]}$ and Andreas Schmidtt ${ }^{*[a]}$
}

\begin{abstract}
Sydnone imines were deprotonated at C4 to give lithiumstabilized anions which proved to be stable for several months in solution. These anions are elements of the intersection of the substance classes of $\mathrm{N}$-heterocyclic carbenes and mesomeric betaines and can be formulated as anionic $\mathrm{N}$-heterocyclic carbenes. The negative charge translates into high-field shifts of the ${ }^{13} \mathrm{C}$ NMR resonance frequencies of $\mathrm{C} 4$ in comparison to other NHCs. Similar to the chemistry of $\mathrm{N}$-heterocyclic carbenes reactions with isocyanates and isothiocyanates gave 4-(N-carbamoyl)benzoylsydnone imines in trapping reactions. As a result of ring transformations involving the characteristic $\pi$-architecture of the mesoionic framework, however, imidazolidine-2,4-dithiones, imidazolin-2,4-diones and 1,2,4-triazol-5-ones were formed depending on the substitution pattern of the starting materials and the reaction conditions.
\end{abstract}

\section{Introduction}

Sydnones 1 (1,2,3-oxadiazolium-5-olates) represent the most prominent structural type of 228 theoretically predicted mesoionic compounds. ${ }^{[1]}$ They are members of the class of conjugated mesomeric betaines $(\mathrm{CMB})$ and belong to class $1 \mathrm{~B}$ according to a recent classification of heterocyclic mesomeric

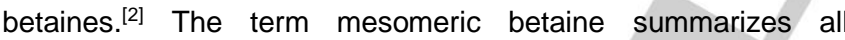
molecules which can exclusively be described by a number of dipolar or tetrapolar resonance forms which delocalize the positive and negative charges within a common $\pi$-electron system. As examples, sydnones can be described by canonical forms such as 1(I), 1(II) and 1(III). The latter two are in agreement with the bond lengths of the exocyclic $\mathrm{C}-\mathrm{O}$ bond which corresponds to a double bond. ${ }^{[3]}$ Sydnones have proven to be versatile 1,3-dipoles for cycloaddition reactions ${ }^{[4]}$ and have displayed various biological activities. ${ }^{[5]}$ In contrast to sydnones, the much lesser examined class of sydnone imines $2(1,2,3$ oxadiazolium-5-aminides) formally possess an exocyclic imine bond as analogously represented by the canonical forms 2(II) and 2(III). ${ }^{[6]}$ The chemistry of sydnone imines such as their hydrolytic or thermal decomposition has been associated with

[a] Tyll Freese, Ana-Luiza Lücke, Jan C. Namyslo, Andreas Schmidt Institute of Organic Chemistry

Clausthal University of Technology

Leibnizstrasse 6, D-38678 Clausthal-Zellerfeld, Germany

E-mail: schmidt@ioc.tu-clausthal.de https://www.ioc.tu-clausthal.de

[b] Martin Nieger

Department of Chemistry, University of Helsinki

P.O Box 55, Fin-00014 University of Helsinki, Finland

Supporting information for this article is given via a link at the end of the document. the high degree of positive charge on N3, whereas the negative partial charge on the exocyclic nitrogen atom is reflected in its basicity. ${ }^{[7]}$ The electron density on $\mathrm{C} 4$ is thought to determine the mode of electrophilic substitution reactions. ${ }^{[7]}$

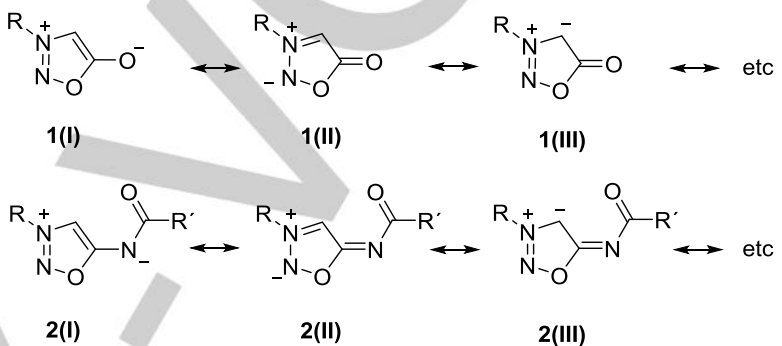

Scheme 1. Some canonical formulae of sydnones 1 and of sydnone imines 2 .

In view of the current interest in anionic heterocyclic carbenes ${ }^{[8]}$ we became interested in studying the anions of sydnones $\mathbf{3}$ and of O-ethyl sydnones $4 .^{[3]}$ Similar to the parent compound, the anions have to be described by several mesomeric forms. Concerning 3, the structures of anionic NHCs and of abnormal anionic NHCs are among the canonical formulae as shown (Scheme 2). By contrast, the deprotonated O-ethylsydnone 4 can be defined as abnormal $\mathrm{N}$-heterocyclic carbene. The fact that the delocalization of the negative charge of $\mathbf{3}$ include the site of deprotonation, i.e. C4, sets these systems apart from most known anionic N-heterocyclic carbenes. Connectivity analyse ${ }^{[2]}$ of sydnone anions reveal that $\mathrm{C} 4$ is a starred (active) position and, correspondingly, large atomic orbital coefficients of the highest occupied molecular orbitals (HOMO) were calculated to be located on $\mathrm{C} 4$, resulting in an ESP partial charge of -0.94 and considerable high-field shifts of the ${ }^{13} \mathrm{C}$ NMR signals.

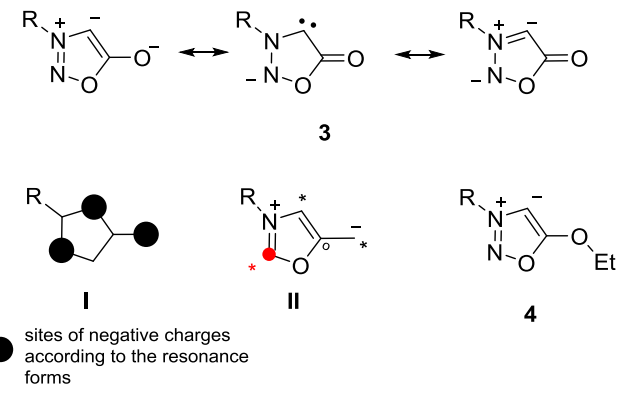

Scheme 2. Sydnone anions 3 and the NHC of O-ethyl sydnone 4. Charge distribution according to the resonance forms (I) and connectivity analysis (II). 
The anions of sydnones form palladium complexes which are catalytically active in cross-coupling reactions. ${ }^{[3],[9]}$ These derivatives of mesoionic compounds are elements of the interesting intersection of the substance classes of mesomeric betaines and $\mathrm{N}$-heterocyclic carbenes. A first review is available. ${ }^{[10]}$ Very recently, a quantitative analysis of factors influencing the ease of formation and $\sigma$-bonding strength of $\mathrm{N}$ heterocyclic carbenes, including those derived from mesomeric betaines, was developed. ${ }^{[11]}$ According to this analysis, $\mathrm{N}$ phenylsydnone has CREF factor (carbene relative energy of formation) of 0.572 which means that deprotonation occurs easier than in diphenylimidazolium-4-olate $(\mathrm{CREF}=0.600) \cdot{ }^{\left[{ }^{[1]}\right]} \mathrm{In}$ continuation of our interest in mesomeric betaines, ${ }^{[12]} \mathrm{N}$ heterocyclic carbenes ${ }^{[13]}$ and the combination of both classes ${ }^{[14]}$ we report here on new and unexpected reactions of sydnone imine anions which prove their Janus-type character.

\section{Results and Discussion}

The sydnone imine hydrochlorides $\mathbf{6} \mathbf{a}, \mathbf{b}$ were prepared from the amines $\mathbf{5 a , b}$ by nucleophilic substitution with haloacetonitriles in reasonable yields according to modified literature procedures concerning the cyclohexyl derivative, ${ }^{[15]}$ followed by $\mathrm{N}$-nitrosation and ring closure reaction on treatment with gaseous hydrochloric acid. Final benzoylation gave the sydnone imines $\mathbf{7 a , b}$ as stable, brownish to yellow-colored compounds which we used as starting materials for further syntheses. The sydnone imine 7c was prepared by a slightly different method which we described in an earlier paper. ${ }^{[16]}$

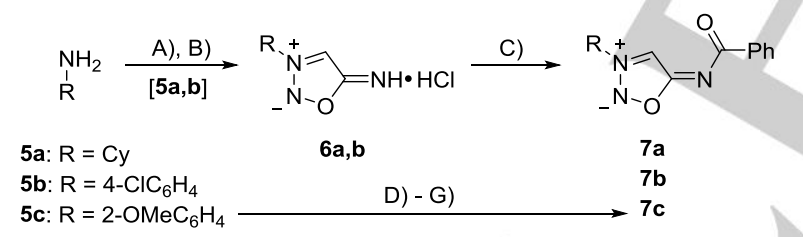

Scheme 3. Reaction conditions starting from 5a: A) 1.1 eq. of $\mathrm{ClCH}_{2} \mathrm{CN}, 2.2$ eq. of $\mathrm{K}_{2} \mathrm{CO}_{3}, \mathrm{MeCN}, 20 \mathrm{~h}$, reflux $(79 \%)^{[39]}$; B) 2.4 eq. of amyl nitrite, $\mathrm{Et}_{2} \mathrm{O}, 20$ $\mathrm{h}$, rt, then $\mathrm{HCl}(\mathrm{g}), 1.5 \mathrm{~h}$, rt $(88 \%)$; C) 1.2 eq. of $\mathrm{PhCOCl}, \mathrm{CH}_{2} \mathrm{Cl}_{2},-10{ }^{\circ} \mathrm{C}$, then 2.4 eq. of $\mathrm{NEt}_{3}(96 \%)$. Reaction conditions starting from $\mathbf{5 b}$ : A) 1.2 eq. of $\mathrm{BrCH}_{2} \mathrm{CN}, 1.2$ eq. of $\mathrm{NaOAc}, \mathrm{EtOH}, 24 \mathrm{~h}$, reflux (73 \%); B) 2.4 eq. of amyl nitrite, $\mathrm{Et}_{2} \mathrm{O}, 20 \mathrm{~h}$, rt, then $\mathrm{HCl}(\mathrm{g}), 1.5 \mathrm{~h}$, rt $(82 \%)$; C) 1.2 eq. of $\mathrm{PhCOCl}$, $\mathrm{CH}_{2} \mathrm{Cl}_{2},-10{ }^{\circ} \mathrm{C}$, then $2.4 \mathrm{NEt}_{3}(76 \%)$. Reaction conditions starting from $5 \mathrm{c}$ : D) $\mathrm{BrCH}_{2} \mathrm{CN}, \mathrm{NaOAc}$, EtOH, reflux (83\%); E) $\left.\mathrm{NaNO}_{2}, \mathrm{HCl}, 0^{\circ} \mathrm{C}(92 \%) ; \mathrm{F}\right) \mathrm{HCl}(\mathrm{g})$, $\mathrm{Et}_{2} \mathrm{O}, 20^{\circ} \mathrm{C}(99 \%)$; G) $\mathrm{PhCOCl}, \mathrm{CH}_{2} \mathrm{Cl}_{2},-10{ }^{\circ} \mathrm{C}$, then $\mathrm{NEt}_{3}(80 \%)$.

Sydnone imines are known to be photochemically and thermally sensitive. ${ }^{[17]}$ Nevertheless we obtained single crystals of sydnone imine 7a by slow evaporation of a chloroform-ethyl acetate mixture in the dark and subjected them to a single crystal X-ray analysis. The exocyclic C-N bond was found to be 131.56(14) $\mathrm{pm}$ which resembles the $\mathrm{C}\left(\mathrm{sp}^{2}\right)=\mathrm{N}$ double bond length of oximes and imines $(128 \mathrm{pm})$ rather than the $\mathrm{C}\left(\mathrm{sp}^{2}\right)-\mathrm{N}$ single bond length of formamide (138 pm).

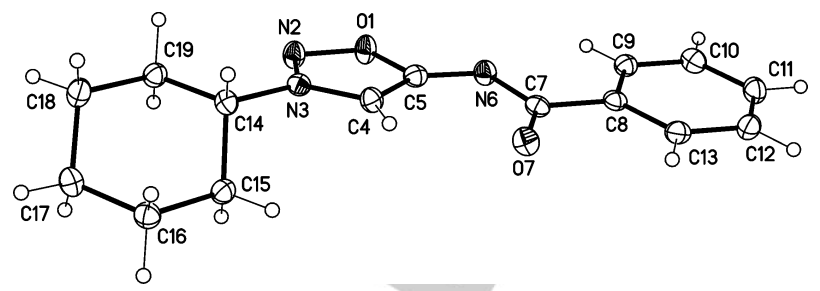

Figure 1. Molecular drawing of 7a (displacement parameters are drawn at $50 \%$ probability level). Selected bond lengths [pm] (crystallographic numbering): N2-N3: 129.71 (13), N3-C4: 134.70 (13), C4-C5: 138.63 (15), C5N6: 131.56 (14), C7-O7: 123.75(13), O7-H4: $238.3 \mathrm{pm}$.

Next we performed a base screening to obtain the anions of sydnone imines for further examinations. The CREF index of 5(acetylimino)-3-methyl-sydnone as a model compound was calculated to be $0.574 .{ }^{[11]}$ Ring cleavages of sydnone imines are known to occur under basic conditions ${ }^{[18]}$ or in water to give $\mathrm{N}$ nitrosoaminoacetamides and $\alpha-(\mathrm{N}$ nitrosobenzylamino)acrylonitrile, respectively. ${ }^{[19]}$ In addition, $N$ acyl-substituted sydnone imines form 4-hydroxy-1,2,3triazoles $^{[20]}$ or pyrazolinones ${ }^{[21]}$ on treatment with hydroxide or aqueous ammonia by means of ring transformations. In the past, nBuLi has been used to initiate several electrophilic attacks at C4, ${ }^{[22]}$ however, these reactions suffer from rapid decompositions at elevated temperatures. ${ }^{[23]}$ In the course of our base screenings we found that $1 \mathrm{M}$ lithium bis(trimethylsilyl)amide in THF at $\mathrm{rt}$ is the best base to accomplish quantitative deprotonations at $\mathrm{C} 4$ of sydnone imines (Scheme 4). Again, several canonical formulae describe the systems, among those mesomeric forms of anionic NHCs, anionic abnormal NHCs as well as by a structure which displays two negative charges on $\mathrm{C} 4$. According to the understanding of mesomerism concerning the distribution of charges in conjugated systems, one of these two negative charges at C4 is due to the exocyclic $\mathrm{sp}^{2}$ orbital, and the other represents the delocalized negative charge within the $\pi$-conjugated system.

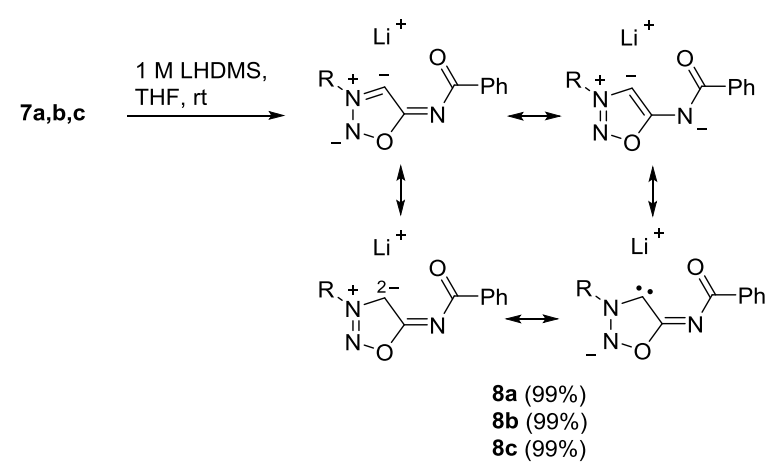

Scheme 4. Sydnone imine anions and their canonical forms.

The deprotonated sydnone imines $\mathbf{8 a - c}$ are stable in THF solutions for several months in the absence of water. ${ }^{13} \mathrm{C}$ NMR spectra show a down field shift at the C4 position (8a: 152.0 ppm, 8b: 154.8 ppm, 8c: 159.8 ppm) in comparison to the starting materials. These values, however, are considerably shifted high-field in comparison to other $\mathrm{N}$-heterocyclic 
carbenes. ${ }^{[10]}$ The role of the lithium cation is crucial for the stabilization of the anions, as potassium ions trigger decomposition. According to a DFT calculation at the B3LYP/6$31 \mathrm{G}(\mathrm{d}, \mathrm{p})$ level the lithium cation is located between the carbene carbon atom and the carbonyl oxygen atom. The 2methoxyphenyl substituent is twisted out of planarity. We calculated the HOMO-1, HOMO and LUMO energies of $8 \mathrm{c}$ to be $-6.39 \mathrm{eV},-5.46 \mathrm{eV}$ and $-1.85 \mathrm{eV}$, respectively. The HOMO-1 includes the $\sigma$ lone pair, whereas the HOMO and LUMO are $\pi$ orbitals, respectively (Fig. 2).
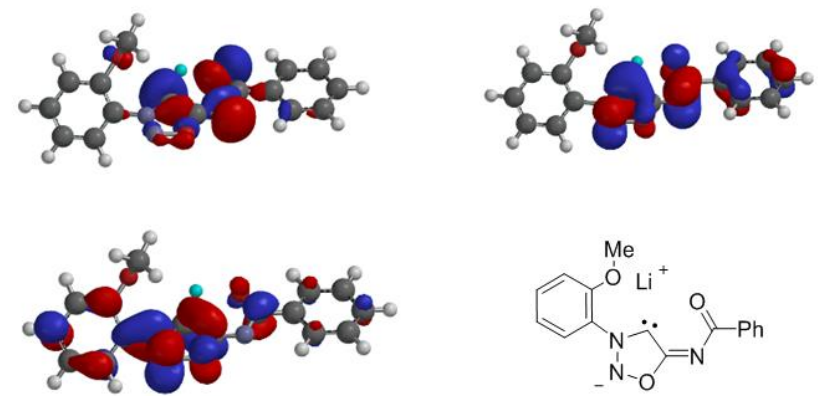

Figure 2. HOMO-1 (above left), HOMO (above right) and LUMO (below) of $\mathbf{8 c}$.

In order to study the covalent bond character of the C-Li bond, we performed ${ }^{7} \mathrm{Li} \mathrm{NMR}$ measurements of $\mathbf{8 c}$. Literature suggests a rising covalent $\mathrm{C}-\mathrm{Li}$ bonding character with increasing downfield shifts in the ${ }^{7} \mathrm{Li} \mathrm{NMR}$ spectra. ${ }^{[24]}$ The ${ }^{7} \mathrm{Li}$ NMR shift of 8c was determined to be $+0.6 \mathrm{ppm}$ (THF-[D]8, rt), whereas the chemical shift for LHMDS is $+0.1 \mathrm{ppm}$ (THF-[D]8, rt, ext. ref. $\mathrm{LiBr})$. Comparison of literature known chemical shifts in THF (nBuLi: $+1.2 \mathrm{ppm}$ at rt; ${ }^{[25]}$ tBuLi: $+0.3 \mathrm{ppm}$ at $-95^{\circ} \mathrm{C} ;{ }^{[26]} \mathrm{LiAlH}_{4}:-$ $0.2 \mathrm{ppm}$ at $\mathrm{rt}^{[27]}$ ) indicates a covalent bond character between tBuLi and nBuLi for the Li-C bond of the carbene $8 \mathrm{c}$. Sydnone imine anions form gold and palladium complexes ${ }^{[16]}$ and undergo reactions with $S^{[28]}$ and Se. ${ }^{[16]}$ To the best of our knowledge, however, the trapping reaction with $\mathrm{CO}_{2}$, isocyanates and isothiocyanates have not yet been described. They are trapping reactions of $\mathrm{N}$-heterocyclic carbenes such as imidazole-2ylidene ${ }^{[29]}$ pyrazol-3-ylidene,$^{[30]}$ indazol-3-ylidene ${ }^{[31]}$ as well as several organo lithium compounds. Thus phenyl lithium reacts with isocyanates, ${ }^{[32]}$ isothiocyanates, ${ }^{[33]}$ and carbon dioxide ${ }^{[34]}$ similarly; the non-complexed phenyl anion was calculated to have a significant carbene character. ${ }^{[35]}$ To study the behavior of sydnone imine anions toward heterocumulenes we reacted freshly prepared samples of deprotonated sydnone imines with tolyl isocyanate, tolyl isothiocyanate and p-chlorophenyl isocyanate. Starting from sydnone imine $7 \mathrm{a}$ the anticipated amides 9,11 and the thioamide 10 were formed at $\mathrm{rt}$ in high yields (Scheme 5). Higher temperatures $\left(<50^{\circ} \mathrm{C}\right)$ gave identical products in similar yields.

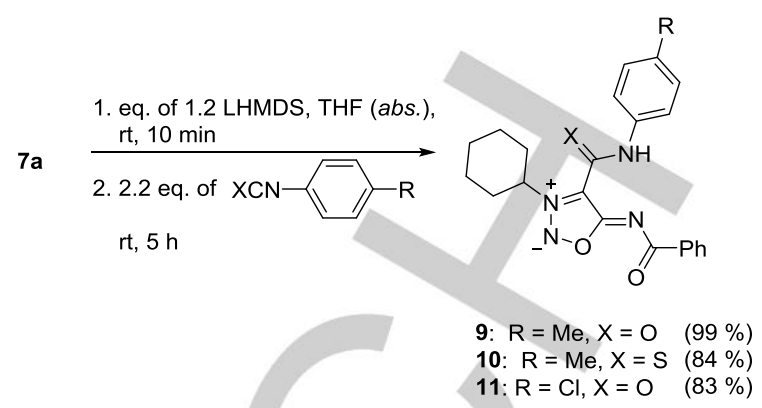

Scheme 5. Amides and thioamides from sydnone imine 7a

When starting from the 3-aryl substituted sydnone imines $\mathbf{7 b}, \mathbf{c}$, however, the 5-arylhydrazono-imidazolidine-2,4-diones or dithiones 12 - 17 and the triazoles 18,19 were formed in moderate yields on reaction with the aforementioned iso(thio)cyanates (Scheme 6). The outcome of the reactions is dependent on the substitution patterns of the substrates, the iso(thio)cyanates, the stoichiometry, and the reaction temperature. Details are summarized in Table 1. The yellow hydrazones 12 and 14 can be isolated when performing the reaction at $-30{ }^{\circ} \mathrm{C}$ with subsequent quenching with water, whereas the corresponding triazoles $\mathbf{1 8}$ and $\mathbf{1 9}$ were formed slowly while warming the reaction mixture to rt. Thus, the $p$ chlorophenyl-substituted sydnone $\mathbf{7 b}$ reacted with isocyanates to give the triazoles 18 and 19 (Table 1, entries 7,8), whereas the less reactive isothiocyanate gave the hydrazone 17 (Table 1 , entry 6).

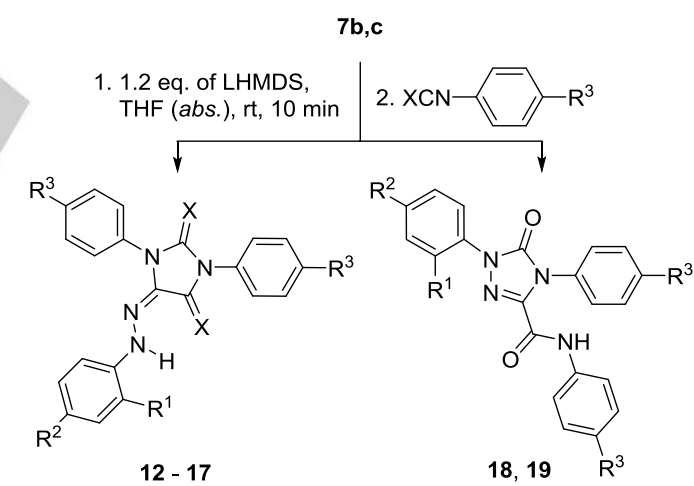

Scheme 6. Formation von arylhydrazones from sydnone imines $7 \mathbf{b}, \mathbf{c}$.

Table 1. Substitution pattern of compounds $12-19$, reaction times, temperatures and yields.

\begin{tabular}{cccccccccc}
\hline Entry & educt & product & $\mathrm{R}^{1}$ & $\mathrm{R}^{2}$ & $\mathrm{R}^{3}$ & $\mathrm{X}$ & $\mathrm{t}$ & $\mathrm{T}$ & yield \\
\hline 1 & $\mathbf{7 b}$ & $\mathbf{1 2}$ & $\mathrm{H}$ & $\mathrm{Cl}$ & $\mathrm{Me}$ & $\mathrm{O}$ & $\mathbf{8 h}$ & $-30^{\circ} \mathrm{C}$ & $30 \%$ \\
2 & $\mathbf{7 b}$ & $\mathbf{1 3}$ & $\mathrm{H}$ & $\mathrm{Cl}$ & $\mathrm{Me}$ & $\mathrm{S}$ & $5 \mathrm{~h}$ & $\mathrm{rt}$ & $47 \%$ \\
3 & $\mathbf{7 b}$ & $\mathbf{1 4}$ & $\mathrm{H}$ & $\mathrm{Cl}$ & $\mathrm{Cl}$ & $\mathrm{O}$ & $\mathbf{8 h}$ & $-30^{\circ} \mathrm{C}$ & $26 \%$ \\
4 & $\mathbf{7 c}$ & $\mathbf{1 5}$ & $\mathrm{OMe}$ & $\mathrm{H}$ & $\mathrm{Me}$ & $\mathrm{O}$ & $5 \mathrm{~h}$ & $\mathrm{rt}$ & $36 \%$ \\
5 & $\mathbf{7 c}$ & $\mathbf{1 6}$ & $\mathrm{OMe}$ & $\mathrm{H}$ & $\mathrm{Me}$ & $\mathrm{S}$ & $5 \mathrm{~h}$ & $\mathrm{rt}$ & $43 \%$ \\
6 & $\mathbf{7 c}$ & $\mathbf{1 7}$ & $\mathrm{OMe}$ & $\mathrm{H}$ & $\mathrm{Cl}$ & $\mathrm{O}$ & $5 \mathrm{~h}$ & $\mathrm{rt}$ & $40 \%$ \\
7 & $\mathbf{7 b}$ & $\mathbf{1 8}$ & $\mathrm{H}$ & $\mathrm{Cl}$ & $\mathrm{Me}$ & - & $5 \mathrm{~h}$ & $\mathrm{rt}$ & $26 \%$ \\
$\mathbf{8}$ & $\mathbf{7 b}$ & $\mathbf{1 9}$ & $\mathrm{H}$ & $\mathrm{Cl}$ & $\mathrm{Cl}$ & - & $5 \mathrm{~h}$ & $\mathrm{rt}$ & $26 \%$ \\
\hline
\end{tabular}


A single crystal X-ray study of $\mathbf{1 5}$ helped to determine the structure (Fig. 3) and displays hydrogen bondings between $\mathrm{O} 4-$ $\mathrm{N} 7-\mathrm{H}$ and $\mathrm{O} 14-\mathrm{N} 7-\mathrm{H}$, resulting in a planar conformation between the o-methoxyphenyl and the imidazolidine ring fragments. The $\mathrm{NH}$-proton is localized at the N7-nitrogenatom in the crystal structure and this is also true in solutions and can be proven by HMBC NMR spectra at rt. The hydrazones show intense yellow (diones) to violet colors (dithiones) with extinction coefficients from $15500(\mathbf{1 3})$ to $33900(\mathbf{1 0}) \mathrm{L} / \mathrm{mol}^{*} \mathrm{~cm}$.

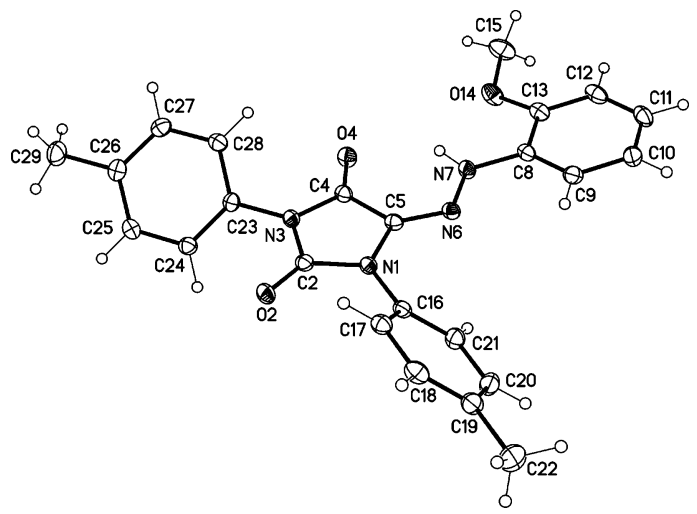

Figure 3. Molecular drawing of $\mathbf{1 5}$ (displacement parameters are drawn at $50 \%$ probability level). Selected bond lengths [pm] (crystallographic numbering): N1-C2: 137.98(14), N1-C5: 141.06(13), C2-O2: 121.33(13), C2N3: 141.04(14), N3-C4: 138.98(14), C4-O4: 121.92(14), C4-C5: 146.93(15), C5-N6: 128.63(14), N6-N7: 134.11(13), O4-H7: 212(1), O14-H7: 227(1) pm.

We propose the following mechanism for the formation of 12 17 (Scheme 7). The sydnone imine carbenes $\mathbf{7 b , c}$ are subsequently trapped by two molecules of isocyanates $(\mathbf{A} \rightarrow \mathbf{B})$. The negative charge of the isocyanate residue of $\mathbf{B}$ induce a ring cleavage of the sydnone imine to give $\mathbf{C}$, the enolate moiety of which attacks the azo group to give $\mathbf{D}$. Formation of benzoyl isocyanate yielded the isolated products 12 - 17.

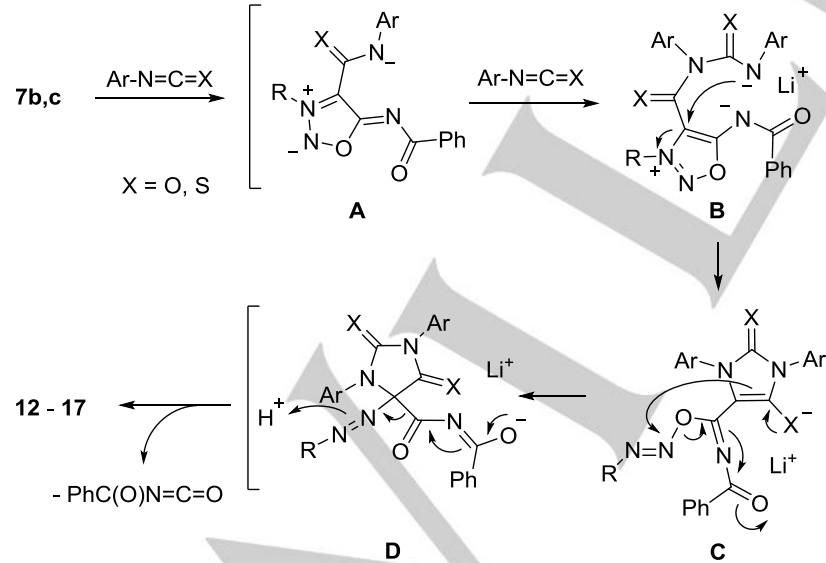

Scheme 7. Proposed mechanism for the formation of $12-17$ by ring transformation.
According to a DFT calculation at the B3LYP/6-31G(d,p) level the HOMO and LUMO of intermediate $7 \mathrm{cB}$ are separated. The HOMO has indeed a large atomic orbital coefficient at the negatively charged nitrogen atom of the northern carbamoyl)(2methoxyphenyl)amidate moiety, whereas the LUMO has a large coefficient at $\mathrm{C} 4$ of the sydnone imine moiety. This step therefore resembles intramolecular charge neutralizations of cross-conjugated mesomeric betaines. ${ }^{[36]}$ Likewise, the HOMO of intermediate $7 \mathrm{cC}$ has large coefficients at the enolate carbon atom, whereas at the azo group large coefficients of the LUMO were calculated.

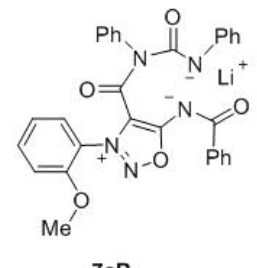

$7 c B$

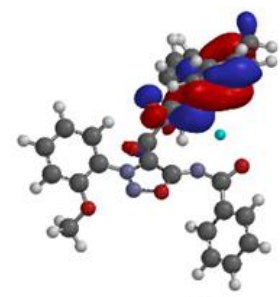

$\mathrm{HOMO}(7 \mathrm{cB})$

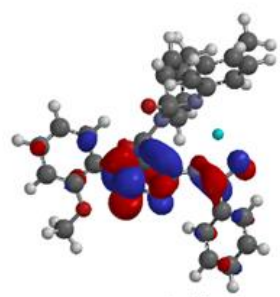

$\operatorname{LUMO}(7 \mathrm{cB})$
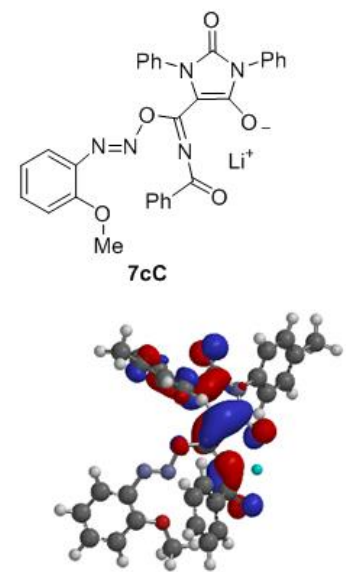

$\mathrm{HOMO}(7 \mathrm{cC})$

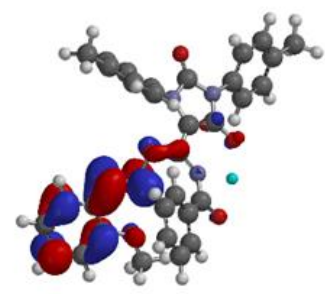

$\operatorname{LUMO}(7 c C)$
Figure 4. Frontier orbital profile of the intermediates 7cB and 7cC.

Further investigation showed the possibility to directly react the hydrazone 12 into the triazole 18 starting from the anion of $\mathbf{1 2}$ (Scheme 8). This is generated by LHMDS at rt and undergoes a [2+3]-cycloaddition with isocyanate and subsequent ring cleavage of the imidazoledione moiety. Extrusion of one molecule of isocyanate gave the triazole $\mathbf{1 8}$ after quenching the reaction mixture. A blind probe was also carried out without addition of isocyanate. Under these conditions, reaction temperatures up to $50^{\circ} \mathrm{C}$ induced no reaction at all. 
12

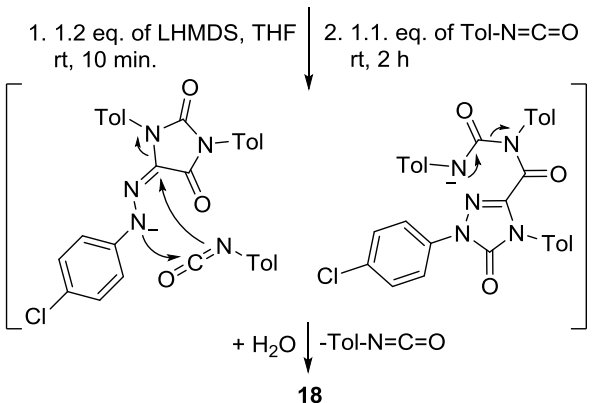

Scheme 8. Transformation of the hydrazone $\mathbf{1 2}$ into triazole $\mathbf{1 8}$

\section{Conclusions}

Sydnone imine anions are elements of the intersection between mesomeric betaines and $\mathrm{N}$-heterocyclic carbenes. They have to be represented by several canonical formulae, among those the structures of anionic NHCs and abnormal anionic NHCs. The $\mathrm{sp}^{2}$ hybrid orbital at $\mathrm{C} 4$ containing the pair of electrons governs its carbene character, whereas the architecture of $\pi$-electrons translates into a mesomeric betaine-like chemical behavior. A large atomic orbital coefficient of the $\mathrm{HOMO}$ at $\mathrm{C} 4$ leads to considerable high-field shifts of the ${ }^{13} \mathrm{C}$ NMR resonance frequencies. Sydnone imine anions were generated by LHMDS in THF at rt. They proved to be stable under exclusion of light and moisture. Depending on the substitution pattern they reacted with isocyanates and isothiocyanates to give (arylcarbamoyl)-3-cyclohexyl-sydnone imines, 1,3-diaryl-5-(2arylhydrazono)-imidazolidine-2,4-diones or 1-aryl-3-(Narylcarbamoyl)-4-aryl-4,5-dihydro-1,2,4-triazol-5-ones as a result of the symphony of $\sigma$ (carbene) and $\pi$ electrons (mesomeric betaine).

\section{Experimental Section}

\section{General consideration}

Flash-chromatography was performed with silica gel 60 (0.040$0.063 \mathrm{~mm}$ ). Nuclear magnetic resonance (NMR) spectra were obtained with a Bruker Avance 400 and Bruker Avance III 600 $\mathrm{MHz} .{ }^{1} \mathrm{H}$ NMR spectra were recorded at $400 \mathrm{MHz}$ or $600 \mathrm{MHz}$ and ${ }^{13} \mathrm{C}$ NMR spectra were measured at $100 \mathrm{MHz}$ or $150 \mathrm{MHz}$, with the solvent peak or tetramethylsilane used as the internal reference. Multiplicities are described by using the following abbreviations: $\mathrm{s}=$ singlet, $\mathrm{d}=$ doublet, $\mathrm{t}=$ triplet, $\mathrm{q}=$ quartet, and $\mathrm{m}=$ multiplet. Signal orientations in DEPT experiments were described as follows: $0=$ no signal; + = up $\left(\mathrm{CH}, \mathrm{CH}_{3}\right)$; - = down $\left(\mathrm{CH}_{2}\right)$. The numbering of the compounds is not necessarily in accordance with IUPAC rules to allow comparisons ("spectroscopic numbering"). FT-IR spectra were obtained on a Bruker Vector 22 in the range of 400 to $4000 \mathrm{~cm}^{-1}$. Melting points were measured by differential scanning calorimetry (DSC) using a DSC 6 apparatus (Perkin Elmer). The electrospray ionization mass spectra (ESIMS) were taken with an Agilent LCMSD series HP 1100 with APIES at a fragmentor voltage of $30 \mathrm{~V}$ unless otherwise noted. Samples were dissolved in $\mathrm{MeOH}$ and sprayed from $\mathrm{MeCN}$ at $4000 \mathrm{~V}$ capillary voltage. The HR-MS spectra were measured on a Bruker Daltonik Tesla-Fourier transform-ion cyclotron resonance mass spectrometer with electrospray ionisation. Yields are not optimized.

\section{Crystal structure determination}

The single-crystal X-ray diffraction study was carried out on a Bruker D8 Venture diffractometer with Photon100 detector at 123(2) $\mathrm{K}$ using Cu-Ka radiation $(\lambda=1.54178 \AA$ ) $(7 \mathrm{a})$ or Mo-Ka radiation $\left(\lambda=0.71073 \AA\right.$ ) $(15)$. Direct Methods (SHELXS-97) ${ }^{[37]}$ were used for structure solution and refinement was carried out using SHELXL-2014 (full-matrix least-squares on F2). ${ }^{[38]}$ Hydrogen atoms were localized by difference electron density determination and refined using a riding model $(\mathrm{H}(\mathrm{N})$ free). Semi-empirical absorption corrections and extinction corrections were applied (see cif-file for details).

7a: colorless crystals, $\mathrm{C}_{15} \mathrm{H}_{17} \mathrm{~N}_{3} \mathrm{O}_{2}, \mathrm{M}=271.32$, crystal size $0.32 \times 0.16 \times 0.08 \mathrm{~mm}$, monoclinic, space group $\mathrm{P} 2_{1} / \mathrm{c}$ (no. 14 ), $a=9.7085(4) \AA, b=17.9600(7) \AA, c=7.7222(3) \AA, \beta=$ 103.236(1) $)^{\circ}, V=1310.71(9) \AA^{3}, Z=4, \rho($ calc $)=1.375 \mathrm{Mg} \mathrm{m}^{-3}$, $\mathrm{F}(000)=576, \mu\left(\mathrm{CuK}_{\alpha}\right)=0.76 \mathrm{~mm}^{-1}, 11915$ reflections $\left(\theta_{\max }=\right.$ $72.2^{\circ}$ ), 2559 unique $\left[R_{\text {int }}=0.020\right.$ ], 182 parameters, $R 1$ (for 2449 $\mathrm{I}>2 \sigma(\mathrm{I}))=0.033$, wR2 (all data) $=0.086, \mathrm{~S}=1.05$, largest diff. peak and hole 0.29 and -0.19 e $\AA^{-3}$.

15: yellow crystals, $\mathrm{C}_{24} \mathrm{H}_{22} \mathrm{~N}_{4} \mathrm{O}_{3}, \mathrm{M}=414.45$, crystal size $0.24 \times 0.20 \times 0.12 \mathrm{~mm}$, triclinic, space group $\mathrm{P}-1$ (no. 2 ), $\mathrm{a}=$ 7.7786(4) $\AA, \quad b=12.1357(8) \AA, \quad c=12.5091(8) \AA, \alpha=$ $117.631(2)^{\circ}, \beta=99.457(2)^{\circ}, \gamma=92.632(2)^{\circ}, V=1021.83(11) \AA^{3}$, $Z=2, \rho($ calc $)=1.347 \mathrm{Mg} \mathrm{m}^{-3}, \mathrm{~F}(000)=436, \mu\left(\mathrm{MoK}_{\alpha}\right)=0.09$ $\mathrm{mm}^{-1}, 41247$ reflections $\left(\theta_{\max }=27.5^{\circ}\right), 4695$ unique $\left[R_{\text {int }}=0.030\right]$, 287 parameters, 1 restraint, $R 1$ (for $4117 \mathrm{I}>2 \sigma(\mathrm{I}))=0.038$, wR2 (all data) $=0.101, S=1.03$, largest diff. peak and hole 0.40 and 0.29 e $\AA^{-3}$.

CCDC 1588012 (7a), and 1588013 (15) contain the supplementary crystallographic data for this paper. These data can be obtained free of charge from The Cambridge Crystallographic Data Centre via www.ccdc.cam.ac.uk/data_request/cif.

\section{Calculations.}

All density-functional theory (DFT)-calculations were carried out by using the current Spartan Software (Spartan'16, Wavefunction, Inc., Irvine, CA. Available from: http://www.wavefun.com) running on an Intel ${ }^{\circledR}$ CoreTM i7-6950X deca-core system equipped with 64 GB RAM main memory and sufficient solid-state disc space. MMFF optimized structures were used as starting geometries. Then, the B3LYP density functional and the 6-31G(d,p) basis set was used. All final structures were proven to be true minima by the absence of 
imaginary frequencies or transition states by the occurrence of a negative frequency.

Synthesis of sydnone imine hydrochloride 6a: Cyclohexylamine (5a) $(5.00 \mathrm{~g}, 50.4 \mathrm{mmol})$, chloroacetonitrile $(4.19 \mathrm{~g}, 55.5 \mathrm{mmol})$, potassium carbonate $(13.94 \mathrm{~g}, 101 \mathrm{mmol})$ and $50 \mathrm{~mL}$ of acetonitrile were combined in a $100 \mathrm{~mL}$ flask and refluxed for $20 \mathrm{~h}$. Afterwards the reaction mixtures were poured into $250 \mathrm{~mL}$ of water. The aqueous phase was extracted with dichloromethane three times, respectively. The combined organic phases were dried over $\mathrm{MgSO}_{4}$ and the solvent was removed under reduced pressure. Further purification of the black liquid was not necessary for the follow-up reaction. Yield: $5.50 \mathrm{~g}(79 \%)$ of a black oil of $\mathrm{N}$-cyclohexyl-aminoacetonitrile. ${ }^{1} \mathrm{H}$ $\operatorname{NMR}\left(400 \mathrm{MHz}, \mathrm{CDCl}_{3}\right): \delta=3.63(\mathrm{~s}, 2 \mathrm{H}, 5-\mathrm{H}), 2.68\left(\mathrm{tt}, J_{H, H} 1=\right.$ $\left.10.2 \mathrm{~Hz}, J_{H, H} 2=3.8 \mathrm{~Hz}, 1 \mathrm{H}, 1-\mathrm{H}\right), 1.83-1.88\left(\mathrm{~m}, 2 \mathrm{H}, 2 / 2^{\prime}-\mathrm{H}\right)$, 1.72-1.78 (m, 2H, 3/3'-H), 1.60-1.67 (m, $1 \mathrm{H}, 4-\mathrm{H}), 1.25-1.36(\mathrm{~m}$, $2 \mathrm{H}, 3 / 3$ '- $\mathrm{H}), 1.14-1.23(\mathrm{~m}, 1 \mathrm{H}, 4-\mathrm{H}), 1.04-1.14\left(\mathrm{~m}, 2 \mathrm{H}, 2 / 2^{\prime}-\mathrm{H}\right)$ ppm. Spectroscopic data are in agreement with those reported in the literature. ${ }^{[39]} \mathrm{A}$ solution of $\mathrm{N}$-cyclohexyl-aminoacetonitrile thus prepared $(5.50 \mathrm{~g}, 39.8 \mathrm{mmol})$ in $35 \mathrm{~mL} \mathrm{Et} \mathrm{O}_{2} \mathrm{O}$ (abs.) in a twonecked flask was treated with isopentyl nitrite $(12.9 \mathrm{~mL}, 95.5$ $\mathrm{mmol}$ ) and stirred at $\mathrm{rt}$ for 20 hours. Afterwards the solution was treated with gaseous hydrochloric acid for 90 minutes. The resulting precipitation was filtered off and washed generously with $\mathrm{Et}_{2} \mathrm{O}$ and DCM. Yield: $7.13 \mathrm{~g}(88 \%)$ of a white solid. ${ }^{1} \mathrm{H}$ NMR (400 MHz, DMSO-d $)$ : 9.87 (s, 2H, 6-H), 8.17 (s, 1H, 4-H), $4.88\left(\mathrm{tt}, J_{H, H} 1=11.3 \mathrm{~Hz}, J_{H, H}=3.8 \mathrm{~Hz}, 1 \mathrm{H}, 7-\mathrm{H}\right), 2.17-2.20(\mathrm{~m}$, $\left.2 \mathrm{H}, 8 / 8^{\prime}-\mathrm{H}\right), 1.81-1.91\left(\mathrm{~m}, 4 \mathrm{H}, 8 / 8^{\prime}-\mathrm{H}+9 / 9^{\prime}-\mathrm{H}\right), 1.62-1.65(\mathrm{~m}, 1 \mathrm{H}$, $10-\mathrm{H}), 1.36-1.47\left(\mathrm{~m}, 2 \mathrm{H}, 9 / 9^{\prime}-\mathrm{H}\right), 1.19-1.30(\mathrm{~m}, 1 \mathrm{H}, 10-\mathrm{H}) \mathrm{ppm}$. Spectroscopic data are in agreement with those reported in the literature. ${ }^{[40]}$

Synthesis of sydnone imine hydrochloride $6 \mathrm{~b}$ : $p$ Chloroaniline $(10.00 \mathrm{~g}, 78.4 \mathrm{mmol})$, bromoacetonitrile $(11.28 \mathrm{~g}$, $94.1 \mathrm{mmol})$, sodium acetate trihydrate $(12.80 \mathrm{~g}, 94.1 \mathrm{mmol})$ and $40 \mathrm{~mL}$ of ethanol were combined in a $100 \mathrm{~mL}$ flask and refluxed for $24 \mathrm{~h}$. Afterwards the reaction mixture was poured into 250 $\mathrm{mL}$ of iced water. The resulting precipitate was filtered off, washed with water and dried in vacuo. Purification was achieved by recrystallization from EtOH. Yield: $9.53 \mathrm{~g}(73 \%)$ of a white solid consistent of $\mathrm{N}$-(p-chlorophenyl)-aminoacetronitrile. ${ }^{1} \mathrm{H}$ $\operatorname{NMR}\left(400 \mathrm{MHz}, \mathrm{CDCl}_{3}\right): \delta=7.19-7.23\left(\mathrm{~m}, 2 \mathrm{H}, 2 / 2^{\prime}-\mathrm{H}\right), 6.60-6.64$ (m, 2H, 3/3'-H), $4.06(\mathrm{~s}, 3 \mathrm{H}, 4-\mathrm{H}+5-\mathrm{H}) \mathrm{ppm}$. Spectroscopic data are in agreement with those reported in the literature. ${ }^{[41]} \mathrm{A}$ solution of $\mathrm{N}$-cyclohexyl-aminoacetonitrile thus prepared $(3.76 \mathrm{~g}$, $22.5 \mathrm{mmol}$ ) in $35 \mathrm{~mL}$ of $\mathrm{Et}_{2} \mathrm{O}$ (abs.) in a two-necked flask was treated with isopentyl nitrite $(7.3 \mathrm{~mL}, 54.1 \mathrm{mmol})$ and stirred at rt for 20 hours. Afterwards the solution was treated with gaseous hydrochloric acid for 90 minutes. The precipitation was filtered off and washed generously with $\mathrm{Et}_{2} \mathrm{O}$. Yield: $4.28 \mathrm{~g}(82 \%)$ of a white solid. ${ }^{1} \mathrm{H}$ NMR $\left(400 \mathrm{MHz}\right.$, DMSO- $\left.d_{6}\right): \delta=10.22$ (s, $2 \mathrm{H}, 6-$ $\mathrm{H}), 8.75(\mathrm{~s}, 1 \mathrm{H}, 4-\mathrm{H}), 8.10-8.13\left(\mathrm{~m}, 2 \mathrm{H}, 8 / 8^{\prime}-\mathrm{H}\right), 7.85-7.87(\mathrm{~m}, 2 \mathrm{H}$, 9/9'-H) ppm. Spectroscopic data are in agreement with those reported in the literature. ${ }^{[18 b]}$
General prodecure for the benzoylation of sydnone imine hydrochlorides 6a-c: A suspension of the sydnone imine hydrochloride, 1.2 eq. of benzoyl chloride and DCM (abs.) was cooled to $-10{ }^{\circ} \mathrm{C}$. Then under vigorous stirring a solution of 2.4 eq. of triethylamine in $5 \mathrm{~mL}$ of DCM (abs.) was added slowly. The mixture was then slowly warmed to $\mathrm{rt}$ and stirred for $16 \mathrm{~h}$. Afterwards $100 \mathrm{~mL}$ of water were added. The aqueous phase was extracted with dichloromethane three times. The combined organic phases were dried over $\mathrm{MgSO}_{4}$ and the solvent was finally removed under reduced pressure.

3-Cyclohexyl-6-benzoylsydnone imine 7a: N-Cyclohexylsydnone imine hydrochloride $(2.00 \mathrm{~g}, 9.82 \mathrm{mmol})$, benzoyl chloride $(1.37 \mathrm{~mL}, 11.78 \mathrm{mmol})$, triethylamine $(3.28 \mathrm{~mL}, 23.57$ $\mathrm{mmol}$ ) and $30 \mathrm{~mL}$ of DCM (abs.) were used. Purification was achieved by column chromatography (silica gel, DCM:MeOH = $30: 1)$. Yield: $2.55 \mathrm{~g}(96 \%)$ of a brownish solid. ${ }^{1} \mathrm{H}$ NMR $(400$ $\left.\mathrm{MHz}, \mathrm{CDCl}_{3}\right): \delta=8.27-8.29\left(\mathrm{~m}, 2 \mathrm{H}, 9 / 9^{\prime}-\mathrm{H}\right), 8.20(\mathrm{~s}, 1 \mathrm{H}, 4-\mathrm{H})$, 7.46-7.51 (m, $1 \mathrm{H}, 11-\mathrm{H}), 7.41-7.45\left(\mathrm{~m}, 2 \mathrm{H}, 10 / 10^{\prime}-\mathrm{H}\right), 4.52$ (tt, $\left.J_{H, H} 1=11.8 \mathrm{~Hz}, J_{H, H}=3.9 \mathrm{~Hz}, 1 \mathrm{H}, 12-\mathrm{H}\right), 2.27-2.31(\mathrm{~m}, 2 \mathrm{H}$, 13/13'-H), 1.96-2.01 (m, 2H, 14/14'-H) 1.83-1.94 (m, 2H, 13/13'$\mathrm{H})$, 1.76-1.81 (m, $1 \mathrm{H}, 15-\mathrm{H}), 1.41-1.52\left(\mathrm{~m}, 2 \mathrm{H}, 14 / 14^{\prime}-\mathrm{H}\right)$, 1.24$1.35(\mathrm{~m}, 1 \mathrm{H}, 15-\mathrm{H}) \mathrm{ppm} ;{ }^{13} \mathrm{C} \mathrm{NMR}\left(100 \mathrm{MHz}, \mathrm{CDCl}_{3}\right): \delta=174.4$ (o, C-5), 174.2 (o, C-7), 137.1 (o, C-8), 129.3 (+, C-11), 129.3 (+, C-9/9'), 127.9 (+, C-10/10'), 104.0 (+, C-4), 64.6 (+, C-12), 32.2 $(-, \quad$ C-13/13'), $24.6 \quad(-, \quad$ C-14/14'), $24.5 \quad(-, \quad C-15) \quad$ ppm. Spectroscopic data are in agreement with those reported in the literature. ${ }^{[15]}$

3-(p-Chlorophenyl)-6-benzoylsydnone imine 7b: $\mathrm{N}$-(pChlorophenyl)-sydnone imine hydrochloride $(0.30 \mathrm{~g}, 1.29 \mathrm{mmol})$, benzoyl chloride $(0.18 \mathrm{~mL}, 1.55 \mathrm{mmol})$, triethylamine $(0.43 \mathrm{~mL}$, $3.10 \mathrm{mmol}$ ) and $10 \mathrm{~mL} \mathrm{DCM} \mathrm{(abs.)} \mathrm{were} \mathrm{used.} \mathrm{Purification} \mathrm{was}$ achieved by column chromatography (silica gel, DCM:MeOH = 30:1). Yield: $0.29 \mathrm{~g}(76 \%)$ of a yellow solid, $\mathrm{mp}: 191{ }^{\circ} \mathrm{C}$ (decomposition). ${ }^{1} \mathrm{H}$ NMR $\left(400 \mathrm{MHz}, \mathrm{CDCl}_{3}\right): \delta=8.65(\mathrm{~s}, 1 \mathrm{H}, 4$ H), 8.26-8.29 (m, 2H, 9/9'-H), 7.79-7.84 (m, 2H, 13/13'- H), 7.58$7.61\left(\mathrm{~m}, 2 \mathrm{H}, 14 / 14^{\prime}-H\right), 7.48-7.52(\mathrm{~m}, 1 \mathrm{H}, 11-H), 7.41-7.45(\mathrm{~m}$, $2 \mathrm{H}, 10 / 10$ '- $\mathrm{H}$ ) ppm; ${ }^{3} \mathrm{C}$ NMR $\left(100 \mathrm{MHz}, \mathrm{CDCl}_{3}\right): \boldsymbol{\delta}=174.5(\mathrm{o}$, C-5), 174.3 (o, C-7), 139.5 (o, C-15), 136.8 (o, C-8), 132.2 (o, C12), 131.7 (+, C-11), 130.8 (+, C-14/14'), $129.5\left(+, \mathrm{C}-9 / 9^{\circ}\right), 128.0$ (+, C-10/10'),122.8 (+, C-13/13'), $104.3(+$, C-4) ppm; IR (ATR): 3187, 3066, 1627, 1553, 1489, 1432, 1314, 1293, 1093, 1067 , $1011,971,946,832,729,707,690,681,662,642,516,497 \mathrm{~cm}$ 1; MS (ESI $30 \mathrm{~V}) \mathrm{m} / \mathrm{z}(\%)=300.0(30)\left[\mathrm{M}+\mathrm{H}^{+}\right]$. HR-ESI-MS: calcd for $\mathrm{C}_{15} \mathrm{H}_{11} \mathrm{~N}_{3} \mathrm{O}_{2} \mathrm{Cl}_{1}{ }^{+} 300.0540$. Found 300.0540 .

General procedure for the sydnone imine deprotonations: Under an inert atmosphere a dry sample of the sydnone imine in an NMR tube was dissolved in anhydrous THF- $\mathrm{d}_{8}$. Then $1.2 \mathrm{eq}$. of a $2 \mathrm{M}$ solution of LHMDS in THF was added to give the lithium adduct in quantitative yields.

4-Lithium-3-cyclohexyl-6-benzoylsydnone imine 8a: 3Cyclohexyl-6-benzoylsydnone imine $(0.021 \mathrm{~g}, 0.077 \mathrm{mmol})$ and a $2 \mathrm{M}$ solution of LHMDS in THF $(0.046 \mathrm{~mL}, 0.093 \mathrm{~mL})$ were used for the deprotonation experiment. ${ }^{1} \mathrm{H}$ NMR $(600 \mathrm{MHz}$, THF- 
$\left.\mathrm{d}_{8}\right): \delta=8.33-8.35\left(\mathrm{~m}, 2 \mathrm{H}, 9 / 9^{\prime}-\mathrm{H}\right), 7.30-7.35\left(\mathrm{~m}, 3 \mathrm{H}, 10 / 10^{\prime}-\mathrm{H}+\right.$ $11-\mathrm{H})$, 4.45-4.50 (m, 1H, 12-H), 2.15-2.18 (m, 2H, Cy-H), 1.96$2.03(\mathrm{~m}, 2 \mathrm{H}, \mathrm{Cy}-\mathrm{H})$ 1.88-1.92 (m, 2H, Cy-H), 1.73-1.78 (m, $1 \mathrm{H}$, Cy-H), 1.45-1.54 (m, 2H, Cy-H), 1.22-1.30 (m, 1H, Cy-H) ppm; ${ }^{13} \mathrm{C}$ NMR (150 MHz, THF-d 8 ): $\boldsymbol{\delta}=185.6$ (o, C-5), 170.2 (o, C-7), 152.0 (o, C-4), 141.1 (o, C-8), 130.1 (+, C-11), 129.8 (+, C-9/9'), 127.8 (+, C-10/10'), 64.3 (+, C-12), 34.4 (-, C-Cy), 26.1 (-, C-Сy), 25.9 (-, C-Сy) ppm.

4-Lithium-3-(p-chlorophenyl)-6-benzoylsydnone imine 8b: 3(p-Chlorophenyl)-6-benzoylsydnone imine $(0.015 \mathrm{~g}, 0.050 \mathrm{mmol})$ and $2 \mathrm{M}$ solution of LHMDS in THF $(0.030 \mathrm{~mL}, 0.060 \mathrm{~mL})$ were used for the deprotonation experiment. ${ }^{1} \mathrm{H}$ NMR $(600 \mathrm{MHz}$, THF$\left.\mathrm{d}_{8}\right): \delta=8.29-8.31\left(\mathrm{~m}, 2 \mathrm{H}, 9 / 9^{\prime}-H\right), 8.14-8.16\left(\mathrm{~m}, 2 \mathrm{H}, 13 / 13^{\prime}-H\right)$, 7.53-7.56 (m, 2H, 14/14'-H), 7.29-7.32 (m, 1H, 11-H), 7.24-7.27 $\left(\mathrm{m}, 2 \mathrm{H}, 10 / 10^{\prime}-H\right)$ ppm. ${ }^{13} \mathrm{C}$ NMR $\left(150 \mathrm{MHz}, \mathrm{THF}-\mathrm{d}_{8}\right): \delta=186.5$ (o, C-5), 171.2 (o, C-7), 154.8 (+, C-4) 139.8 (o, C-15), 140.7 (o, C-8), 136.4 (o, C-12), $130.4(+$, C-11), $130.2(+$, C-14/14'), 130.0 (+, C-9/9'), $127.9(+$, C-10/10`), $123.9(+$, C-13/13'),ppm.

4-Lithium-3-(0-methoxyphenyl)-6-benzoylsydnone imine 8c: 3-(o-Methoxyphenyl)-6-benzoylsydnone imine (0.022 g, 0.075 $\mathrm{mmol})$ and $2 \mathrm{M}$ solution of LHMDS in THF $(0.045 \mathrm{~mL}, 0.089 \mathrm{~mL})$ were used for the deprotonation experiment. ${ }^{1} \mathrm{H} \mathrm{NMR}(600 \mathrm{MHz}$, THF- $\left.\mathrm{d}_{8}\right): \delta=8.25-8.24\left(\mathrm{~m}, 2 \mathrm{H}, 9 / 9^{\prime}-\mathrm{H}\right), 7.48-7.51(\mathrm{~m}, 1 \mathrm{H}, 15-\mathrm{H})$, 7.46-7.47 (m, $1 \mathrm{H}, 17-\mathrm{H}), 7.22-7.25(\mathrm{~m}, 1 \mathrm{H}, 11-\mathrm{H}), 7.19-7.20(\mathrm{~m}$, $1 \mathrm{H}, 14-\mathrm{H}), 7.13-7.16\left(\mathrm{~m}, 2 \mathrm{H}, 10 / 10^{\prime}-\mathrm{H}\right), 7.05-7.07(\mathrm{~m}, 1 \mathrm{H}, 16-\mathrm{H})$, $3.73(\mathrm{~s}, 3 \mathrm{H}, 19-\mathrm{H}) \mathrm{ppm} \cdot{ }^{[16]}{ }^{13} \mathrm{C}$ NMR $\left(150 \mathrm{MHz}, \mathrm{THF}-\mathrm{d}_{8}\right): \delta=$ 185.4 (o, C5), 170.4 (o, C7), 159.8 (o, C4), 154.9 (o, C13), 140.8 (o, C8), $131.8(+, \mathrm{C} 15), 130.8$ (o, C12), $130.1(+, \mathrm{C} 11), 129.8(+$, C9/C9), $128.2(+, \mathrm{C} 17), 127.9\left(+, \mathrm{C} 10 / \mathrm{C} 10^{\prime}\right), 121.0(+, \mathrm{C} 16)$, $113.4(+, \mathrm{C} 14), 56.1$ (+, C19) ppm. ${ }^{7} \mathrm{Li}$ NMR $\left(233 \mathrm{MHz}, \mathrm{THF}-\mathrm{d}_{8}\right)$ : $\delta=0.58 \mathrm{ppm}$.

General procedure for the sydnone imine carbene generation and subsequent reaction with isocyanates / isothiocyanates: Under an inert atmosphere the sydnone imines were solved in THF (abs.) and treated with a $2 \mathrm{M}$ solution of LHMDS in THF. After stirring for 10 minutes at $\mathrm{rt}$ the isocyanates/isothiocyanates were added. An immediate change of color was be observed. The reaction mixture was stirred for 5 $\mathrm{h}$, then combined with silica gel and purified by column chromatography.

\section{4-(N-(p-Methylphenyl)carbamoyl)-3-cyclohexyl-6-benzoyl-} sydnone imine 9: 3-Cyclohexyl-6-benzoylsydnone imine $(0.271$ $\mathrm{g}, 1.00 \mathrm{mmol}), 2 \mathrm{M}$ of LHMDS in THF (0.60 mL, $1.20 \mathrm{mmol})$, 4tolyl isocyanate $(0.28 \mathrm{~mL}, 2.20 \mathrm{mmol})$ and $12 \mathrm{~mL}$ THF (abs.) were used. Purification was achieved by column chromatography (silica gel, DCM:MeOH = 100:1). Yield: $0.399 \mathrm{~g}$ (99\%) of a white solid, mp: $198{ }^{\circ} \mathrm{C}$ (decomposition). ${ }^{1} \mathrm{H}-\mathrm{NMR}$ $\left(600 \mathrm{MHz}, \mathrm{CDCl}_{3}\right): \delta=11.21(\mathrm{~s}, 1 \mathrm{H}, 17-\mathrm{H}), 8.24-8.25(\mathrm{~m}, 2 \mathrm{H}$, 9/9'-H), 7.55-7.56 (m, 2H, 19/C19'-H), 7.53-7.57 (m, 1H, 11-H), 7.46-7.48 (m, 2H, 10/10'-H), 7.18-7.19 (m, 2H, 20/20'-H), 5.94 (tt $\left.J_{H, H}=11.6 \mathrm{~Hz}, J_{H, H} 2=3.6 \mathrm{~Hz}, 1 \mathrm{H}, 12-\mathrm{H}\right), 2.37-2.39(\mathrm{~m}, 2 \mathrm{H}$, 13/13'-H), 2.35 (s. 3H, 22-H), 1.93-2.01 (m, 4H, 13/13'-H + $\left.14 / 14^{\prime}-\mathrm{H}\right), 1.80-1.82(\mathrm{~m}, 1 \mathrm{H}, 15-\mathrm{H}), 1.54-1.61$ (m, 2H, 14/14'-H),
1.30-1.37 (m, 1H, 15-H) ppm; ${ }^{13} \mathrm{C}$ NMR $\left(150 \mathrm{MHz}, \mathrm{CDCl}_{3}\right): \boldsymbol{\delta}=$ 172.1 (o, C-7), 165.5 (o, C-5), 153.8 (o, C-16), 136.7 (o, C-8), 134.9 (o, C-21), 134.8 (o, C-18), 132.2 (+, C-11), 129.9 (+, C20/20'), $129.4(+$, C-9/9'), $128.4(+$, C-10/10'), 120.2 (+, C19/19'), 107.4 (o, C-4), 65.8 (+, C-12), 32.6 (-, C-13/13'), 25.2 (-, C-14/14'), 24.9 (-, C-15), 21.1 (+, C-22) ppm; IR (ATR): 3175, $3116,3053,2936,2853,1674,1635,1606,1574,1549,1512$, 1447, 1396, 1369, 1307, 1277, 1261, 1234, 1178, 1035, 1018, $902,869,828,805,741,712,693,591,536,508 \mathrm{~cm}^{-1}$; MS (ESI $30 \mathrm{~V}) \mathrm{m} / \mathrm{z}(\%)=427.1(30)\left[\mathrm{M}_{+} \mathrm{Na}^{+}\right], 831.5(100)\left[2 \mathrm{M}+\mathrm{Na}^{+}\right]$. HRESI-MS: calcd for $\mathrm{C}_{23} \mathrm{H}_{25} \mathrm{~N}_{4} \mathrm{O}_{3}{ }^{+}$405.1927. Found 405.1926.

\section{4-(N-(p-Methylphenyl)carbamothioyl)-3-cyclohexyl-6-}

benzoylsydnone imine 10: 3-Cyclohexyl-6-benzoylsydnone imine $(0.271 \mathrm{~g}, 1.00 \mathrm{mmol}), 2 \mathrm{M}$ of LHMDS in THF $(0.60 \mathrm{~mL}$, $1.20 \mathrm{mmol})$, 4-tolyl isothiocyanate $(0.328 \mathrm{~g}, 2.20 \mathrm{mmol})$ and 12 $\mathrm{mL}$ of THF (abs.) were used. Purification was achieved by column chromatography (silica gel, DCM:PE = 10:1). Yield: $0.352 \mathrm{~g}(84 \%)$ of a yellow solid, $\mathrm{mp}: 171^{\circ} \mathrm{C}$ (decomposition). ${ }^{1} \mathrm{H}$ NMR (400 MHz, CDCl $)$ ): $\boldsymbol{\delta}=13.47(\mathrm{~s}, 1 \mathrm{H}, 17-\mathrm{H}), 8.15-8.18(\mathrm{~m}$, $\left.2 \mathrm{H}, 9 / 9^{\prime}-\mathrm{H}\right), 7.64-7.66\left(\mathrm{~m}, 2 \mathrm{H}, 19 / \mathrm{C} 19^{\prime}-\mathrm{H}\right), 7.49-7.54(\mathrm{~m}, 1 \mathrm{H}, 11-$ $\mathrm{H})$, 7.40-7.46 (m, 2H, 10/10'-H), 7.24-7.26 (m, 2H, 20/20'-H), 6.97 (tt, $\left.J_{H, H} 1=11.4 \mathrm{~Hz}, J_{H, H} 2=3.5 \mathrm{~Hz}, 1 \mathrm{H}, 12-\mathrm{H}\right), 2.44-2.47(\mathrm{~m}$, $\left.2 \mathrm{H}, 13 / 13^{\prime}-\mathrm{H}\right), 2.39$ (s. 3H, 22-H), 1.90-2.00 (m, 4H, 13/13'- $\mathrm{H}+$ $\left.14 / 14^{\prime}-\mathrm{H}\right), 1.79-1.83(\mathrm{~m}, 1 \mathrm{H}, 15-\mathrm{H}), 1.50-1.62\left(\mathrm{~m}, 2 \mathrm{H}, 14 / 14^{\prime}-\mathrm{H}\right)$, 1.28-1.38 (m, $1 \mathrm{H}, 15-\mathrm{H}) \mathrm{ppm} ;{ }^{13} \mathrm{C}$ NMR $\left(100 \mathrm{MHz}, \mathrm{CDCl}_{3}\right): \boldsymbol{\delta}=$ 176.1 (o, C-16), 172.0 (o, C-7), 163.4 (o, C-5), 137.3 (o, C-21), 136.3 (o, C-8), 135.6 (o, C-18), $132.3(+, \mathrm{C}-11), 129.7(+, \mathrm{C}$ 20/20'), $129.4(+$, C-9/9'), $128.4(+$, C-10/10'), $124.2(+$, C 19/19'), 111.6 (o, C-4), 65.9 (+, C-12), 32.9 (-, C-13/13'), 25.2 (C-14/14'), 24.9 (-, C-15), 21.3 (+, C-22) ppm; IR (ATR): 2936, 2855, 1640, 1600, 1564, 1506, 1448, 1392, 1307, 1253, 1231, $1045,1020,817,756,737,708,571,505,449 \mathrm{~cm}^{-1}$; MS (ESI 30 V) $\mathrm{m} / \mathrm{z}(\%)=443.1(100)\left[\mathrm{M}+\mathrm{Na}^{+}\right], 863.5(80)\left[2 \mathrm{M}+\mathrm{Na}^{+}\right]$. HRESI-MS: calcd for $\mathrm{C}_{23} \mathrm{H}_{25} \mathrm{~N}_{4} \mathrm{O}_{2} \mathrm{~S}_{1}{ }^{+} 421.1698$. Found 421.1700.

\section{4-(N-(p-Chlorophenyl)carbamoyl)-3-cyclohexyl-6-}

benzoylsydnone imine 11: 3-Cyclohexyl-6-benzoylsydnone imine $(0.200 \mathrm{~g}, 0.74 \mathrm{mmol}), 2 \mathrm{M}$ of LHMDS in THF $(0.44 \mathrm{~mL}$, $0.89 \mathrm{mmol})$, 4-chlorophenyl-isocyanate $(0.249 \mathrm{~g}, 1.62 \mathrm{mmol})$ and $12 \mathrm{~mL}$ of THF (abs.) were used. Purification was achieved by column chromatography (silica gel, DCM:PE = 10:1). Yield: $0.261 \mathrm{~g}(83 \%)$ of a white solid, $\mathrm{mp}: 182{ }^{\circ} \mathrm{C}$ (decomposition). ${ }^{1} \mathrm{H}$ NMR (400 MHz, CDCl 3 ): $\boldsymbol{\delta}=11.33(\mathrm{~s}, 1 \mathrm{H}, 17-\mathrm{H}), 8.20-8.23(\mathrm{~m}$, $\left.2 \mathrm{H}, 9 / 9^{\prime}-\mathrm{H}\right), 7.60-7.64\left(\mathrm{~m}, 2 \mathrm{H}, 19 / \mathrm{C} 19^{\prime}-\mathrm{H}\right), 7.54-7.58(\mathrm{~m}, 1 \mathrm{H}, 11-$ $\mathrm{H})$, 7.46-7.50 (m, 2H, 10/10'-H), 7.33-7.36 (m, 2H, 20/20'-H), $5.89\left(\mathrm{tt}, J_{H, H} 1=11.5 \mathrm{~Hz}, J_{H, H} 2=3.6 \mathrm{~Hz}, 1 \mathrm{H}, 12-\mathrm{H}\right), 2.37-2.39(\mathrm{~m}$, $\left.2 \mathrm{H}, 13 / 13^{\prime}-\mathrm{H}\right), 1.92-2.00\left(\mathrm{~m}, 4 \mathrm{H}, 13 / 13^{\prime}-\mathrm{H}+14 / 14^{\prime}-\mathrm{H}\right), 1.81-1.84$ $(\mathrm{m}, 1 \mathrm{H}, 15-\mathrm{H}), 1.51-1.63\left(\mathrm{~m}, 2 \mathrm{H}, 14 / 14^{\prime}-\mathrm{H}\right), 1.28-1.40(\mathrm{~m}, 1 \mathrm{H}$, $15-\mathrm{H}) \mathrm{ppm} ;{ }^{13} \mathrm{C}$ NMR $\left(100 \mathrm{MHz}, \mathrm{CDCl}_{3}\right): \boldsymbol{\delta}=172.0(\mathrm{o}, \mathrm{C}-7)$, 165.4 (o, C-5), 153.9 (o, C-16), 136.6 (o, C-8), 136.0 (o, C-18), 132.4 (+, C-11), 130.2 (o, C-21), 129.5 (+, C-20/20'), $129.4(+$, C-9/9'), 128.5 (+, C-10/10'), 121.4 (+, C-19/19'), 107.1 (o, C-4), 66.0 (+, C-12), 32.6 (-, C-13/13'), 25.2 (-, C-14/14'), 24.9 (-, C 15) ppm; IR (ATR): 3234, 3112, 3057, 2933, 2849, 1677, 1640, $1602,1577,1548,1489,1448,1395,1366,1334,1307,1266$, $1183,1169,1086,1037,1021,898,870,825,762,708,689$, 
$584,507,454,439 \mathrm{~cm}^{-1}$; MS (ESI $\left.30 \mathrm{~V}\right) \mathrm{m} / \mathrm{z}(\%)=447.1(100)$ $\left[\mathrm{M}+\mathrm{Na}^{+}\right], \quad 871.3 \quad(60) \quad\left[2 \mathrm{M}+\mathrm{Na}^{+}\right] . \quad$ HR-ESI-MS: calcd for $\mathrm{C}_{22} \mathrm{H}_{21} \mathrm{~N}_{4} \mathrm{O}_{3} \mathrm{Cl}_{1} \mathrm{Na}^{+}$447.1200. Found 447.1200.

\section{1,3-Di-(4-methylphenyl)-5-(2-(4-chlorophenyl)-hydrazono)- imidazolidine-2,4-dione 12: 3-(4-Chlorophenyl)-6- benzoylsydnone imine $(0.300 \mathrm{~g}, 1.00 \mathrm{mmol}), 2 \mathrm{M}$ of LHMDS in THF $(0.60 \mathrm{~mL}, 1.20 \mathrm{mmol})$, 4-tolyl isocyanate $(0.28 \mathrm{~mL}, 2.20$ $\mathrm{mmol}$ ) and $12 \mathrm{~mL}$ of THF (abs.) were used. The reaction was stirred at $-30^{\circ} \mathrm{C}$ for $8 \mathrm{~h}$ and then quenched with $1 \mathrm{~mL}$ of water. Purification was achieved by column chromatography (silica gel, DCM). Yield: $0.127 \mathrm{~g}(30 \%)$ of a yellow solid, mp: $221{ }^{\circ} \mathrm{C} .{ }^{1} \mathrm{H}$ NMR (400 MHz, $\left.\mathrm{CDCl}_{3}\right): \boldsymbol{\delta}=11.07(\mathrm{~s}, 1 \mathrm{H}, 17-\mathrm{H}), 7.45-7.47(\mathrm{~m}$, $\left.2 \mathrm{H}, 7 / 7^{\prime}-\mathrm{H}\right), 7.37-7.40\left(\mathrm{~m}, 2 \mathrm{H}, 12 / 12^{\prime}-\mathrm{H}\right) 7.31-7.33\left(\mathrm{~m}, 2 \mathrm{H}, 8 / 8^{\prime}-\mathrm{H}\right)$ 7.30-7.32 (m, 2H, 13/13'-H), 7.18-7.21 (m, 2H, 20/20'-H), 6.94- $6.98\left(\mathrm{~m}, 2 \mathrm{H}, 19 / 19^{\prime}-\mathrm{H}\right), 2.43(\mathrm{~s}, 3 \mathrm{H}, 10-\mathrm{H}), 2.41(\mathrm{~s}, 3 \mathrm{H}, 15-\mathrm{H})$ ppm; ${ }^{13} \mathrm{C}$ NMR $\left(100 \mathrm{MHz}, \mathrm{CDCl}_{3}\right.$ ): $\boldsymbol{\delta}=156.7$ (o, C-4), 150.7 (o, C-2), 141.9 (o, C-18), 138.9 (o, C-14), 138.0 (o, C-9), 130.0 (+, C-8/8'), 129.9 (+, C-13/13'), 129.5 (o, C-6), 129.4 (+, C-20/20'), 127.9 (o, C-11), 126.7 (o, C-21), 126.3 (o, C-5), $126.2\left(+, \mathrm{C} 7 / 7^{\prime}\right)$, 125.9 (+, C-12/12'), 114.3 (+, C-19/19'), $21.4(+$, C-10 + C-15) ppm; IR (ATR): 3297, 3037, 2921, 1761, 1699, 1616, 1600, $1502,1406,1235,1136,1093,943,898,817,806,762,736$, 642 , 582, 509, $420 \mathrm{~cm}^{-1}$; MS (ESI $\left.30 \mathrm{~V}\right) \mathrm{m} / \mathrm{z}(\%)=471.1(100)$ $\left[\mathrm{M}-\mathrm{H}^{+}\right]$. HR-ESI-MS: calcd for $\mathrm{C}_{23} \mathrm{H}_{19} \mathrm{~N}_{4} \mathrm{O}_{2} \mathrm{Cl}_{1} \mathrm{Na}^{+} 441.1094$. Found 441.1092.}

\section{1,3-Di-(4-methylphenyl)-5-(2-(4-chloroyphenyl)-hydrazono)-} imidazolidine-2,4-dithione 13: 3-(4-Chlorophenyl)-6benzoylsydnone imine $(0.300 \mathrm{~g}, 1.00 \mathrm{mmol}), 2 \mathrm{M}$ of LHMDS in THF (0.60 mL, $1.20 \mathrm{mmol})$, 4-tolyl isothiocyanate $(0.328 \mathrm{~g}, 2.20$ $\mathrm{mmol}$ ) and $12 \mathrm{~mL}$ of THF (abs.) were used. Purification was achieved by column chromatography (silica gel, DCM). Yield: $0.181 \mathrm{~g}(40 \%)$ of a red solid, mp: $273{ }^{\circ} \mathrm{C}$ (decomposition). ${ }^{1} \mathrm{H}$ $\operatorname{NMR}\left(600 \mathrm{MHz}, \mathrm{CDCl}_{3}\right): \boldsymbol{\delta}=14.41(\mathrm{~s}, 1 \mathrm{H}, 17-\mathrm{H}), 7.39-7.41(\mathrm{~m}$, $\left.6 \mathrm{H}, 8 / 8^{\prime}-\mathrm{H}+12 / 12^{\prime}-\mathrm{H}+13 / 13^{\prime}-\mathrm{H}\right), 7.27-7.28\left(\mathrm{~m}, 2 \mathrm{H}, 7 / 7^{\prime}-\mathrm{H}\right)$, 7.22-7.25 (m, 2H, 20/20'-H), 7.04-7.06 (m, 2H, 19/19'-H), 2.48 (s $3 \mathrm{H}, 15-\mathrm{H}), 2.46$ (s, 3H, 10-H) ppm; ${ }^{13} \mathrm{C}$ NMR $\left(150 \mathrm{MHz}, \mathrm{CDCl}_{3}\right)$ : $\delta=174.0$ (o, C-4), 171.2 (o, C-2), 140.6 (o, C-18), 140.3 (o, C-9) 139.5 (o, C-14), 133.8 (o, C-5), 132.0 (o, C-6), 131.5 (o, C-11), $130.4(+$, C-8/8'), $130.1(+$, C-13/13'), 129.8 (+, C-20/20'), 129.4 (o, C-21), $128.6(+$, C7/7'), $128.4(+$, C-12), 116.4 (+, C-19), 21.6 (+, C-10) 21.6 (+, C-15) ppm; IR (ATR): 3038, 2961, 2919, 2856, $1564,1511,1479,1422,1389,1320,1258,1218,1145,1082$, $982,884,801,761,724,632,607,574,518,508,416 \mathrm{~cm}^{-1}$; MS $(\mathrm{ESI} 30 \mathrm{~V}) \mathrm{m} / \mathrm{z}(\%)=473.0(100)\left[\mathrm{M}+\mathrm{Na}^{+}\right]$. HR-ESI-MS: calcd for $\mathrm{C}_{23} \mathrm{H}_{19} \mathrm{~N}_{4} \mathrm{~S}_{2} \mathrm{Cl}_{1} \mathrm{Na}^{+}$473.0637. Found 473.0641.

1,3-Di-(4-chlorophenyl)-5-(2-(4-chlorophenyl)-hydrazono)imidazolidine-2,4-dione 14: 3-(4-Chlorophenyl)-6-benzoylsydnone imine $(0.300 \mathrm{~g}, 1.00 \mathrm{mmol}), 2 \mathrm{M}$ of LHMDS in THF $(0.75 \mathrm{~mL}, 1.50 \mathrm{mmol})$, 4-chlorophenyl isocyanate $(0.369 \mathrm{~g}, 2.40$ $\mathrm{mmol}$ ) and $12 \mathrm{~mL}$ of THF (abs.) were used. The reaction was stirred at $-30^{\circ} \mathrm{C}$ for $8 \mathrm{~h}$ and then quenched with $1 \mathrm{~mL}$ of water. Purification was achieved by column chromatography (silica gel, DCM). Yield: $0.119 \mathrm{~g} \mathrm{(26 \% )}$ of a yellow solid, mp: $261{ }^{\circ} \mathrm{C} .{ }^{1} \mathrm{H}$ $\operatorname{NMR}\left(600 \mathrm{MHz}, \mathrm{CDCl}_{3}\right): \delta=11.06(\mathrm{~s}, 1 \mathrm{H}, 15-\mathrm{H}), 7.54-7.57(\mathrm{~m}$, $\left.2 \mathrm{H}, 7 / 7^{\prime}-\mathrm{H}\right), 7.50-7.52\left(\mathrm{~m}, 2 \mathrm{H}, 8 / 8^{\prime}-\mathrm{H}\right) 7.50$ (s, 4H, 11/11'/12/12'H), 7.22-7.25 (m, 2H, 18/18'-H), 6.97-6.99 (m, 2H, 17/17'-H) ppm; ${ }^{13} \mathrm{C}$ NMR (150 MHz, $\left.\mathrm{CDCl}_{3}\right): \delta=156.0$ (o, C-4), 150.0 (o, C-2), 141.5 (o, C-16), 134.8 (o, C-13), 133.8 (o, C-6), 130.5 (o, C-9), 129.7 (+, C-11/11'), 129.6 (+, C-18/18'), 129.5 (+, C-7/7'), 129.0 (o, C-10), 127.5 (+, C8/8'), 127.3 (o, C-19), 127.2 (+, C12/12'), 125.3 (o, C-5), 114.5 (+, C-17/17') ppm; IR (ATR): 3266 , 3098, 1754, 1699, 1599, 1491, 1396, 1235, 1133, 1092, 1014, $941,898,816,792,759,549,506,481 \mathrm{~cm}^{-1}$; MS (ESI $\left.30 \mathrm{~V}\right) \mathrm{m} / \mathrm{z}$ $(\%)=459.0(100)\left[\mathrm{M}-\mathrm{H}^{+}\right]$. HR-ESI-MS: calcd for $\mathrm{C}_{21} \mathrm{H}_{12} \mathrm{~N}_{4} \mathrm{O}_{2} \mathrm{Cl}_{3}$ 457.0026. Found 457.0023.

1,3-Di-(4-methylphenyl)-5-(2-(2-methoxyphenyl)-hydrazono)imidazolidine-2,4-dione 15: 3-(2-Methoxyphenyl)-6benzoylsydnone imine $(0.295 \mathrm{~g}, 1.00 \mathrm{mmol}), 2 \mathrm{M}$ of LHMDS in THF $(0.60 \mathrm{~mL}, 1.20 \mathrm{mmol})$, 4-tolyl isocyanate $(0.15 \mathrm{~mL}, 1.20$ $\mathrm{mmol}$ ) and $12 \mathrm{~mL}$ of THF (abs.) were used. Purification was achieved by column chromatography (silica gel, DCM:MeOH = 300:1). Yield: $0.196 \mathrm{~g}(47 \%)$ of a yellow solid, mp: $230{ }^{\circ} \mathrm{C} .{ }^{1} \mathrm{H}$ NMR $\left(400 \mathrm{MHz}, \mathrm{CDCl}_{3}\right): \delta=11.35(\mathrm{~s}, 1 \mathrm{H}, 17-\mathrm{H}), 7.48-7.51(\mathrm{~m}$, $\left.2 \mathrm{H}, 7 / 7^{\prime}-\mathrm{H}\right), 7.40-7.42\left(\mathrm{~m}, 2 \mathrm{H}, 12 / 12^{\prime}-\mathrm{H}\right), 7.27-7.33\left(\mathrm{~m}, 5 \mathrm{H}, 8 / 8^{\prime} \mathrm{H}\right.$ $\left.+13 / 13^{\prime}-\mathrm{H}+23-\mathrm{H}\right), 6.86-6.90(\mathrm{~m}, 2 \mathrm{H}, 21-\mathrm{H}+22-\mathrm{H}), 6.83-6.85$ $(\mathrm{m}, 1 \mathrm{H}, 20-\mathrm{H}), 3.88(\mathrm{~s}, 3 \mathrm{H}, 25-\mathrm{H}), 2.43(\mathrm{~s}, 3 \mathrm{H}, 10-\mathrm{H}), 2.40(\mathrm{~s}, 3 \mathrm{H}$, $15-\mathrm{H})$ ppm; ${ }^{13} \mathrm{C}$ NMR $\left(100 \mathrm{MHz}, \mathrm{CDCl}_{3}\right): \delta=156.4$ (o, C-4), 150.7 (o, C-2), 146.3 (o, C-19), 138.8 (o, C-14), 137.7 (o, C-9), 132.8 (o, C-18), 130.0 (+, C-13/13'), 129.8 (o, C-6), 129.8 (+, C8/8'), 128.1 (o, C-11), 126.4 (o, C-5), 126.3 (+, C-7/7'), $126.0(+$, C12/12'), $121.5(+, \mathrm{C}-21), 121.5$ (+, C-22), 112.1 (+, C-23), 110.5 (+, C-20), 55.8 (+, C-25), $21.4(+$, C-10 + C15) ppm; IR (ATR): 3292, 2992, 2853, 1743, 1703, 1600, 1512, 1464, 1437, 1394, 1268, 1224, 1173, 1133, 1021, 938, 835, 804, 746, 606, $577,507,430 \mathrm{~cm}^{-1}$; MS (ESI $30 \mathrm{~V}$ ) $\mathrm{m} / \mathrm{z}(\%)=437.0(100)$ [M+Na+]. HR-ESI-MS: calcd for $\mathrm{C}_{24} \mathrm{H}_{22} \mathrm{~N}_{4} \mathrm{O}_{3} \mathrm{Na}^{+} 437.1590$. Found 437.1588.

1,3-Di-(4-methylphenyl)-5-(2-(2-methoxyphenyl)-hydrazono)imidazolidine-2,4-dithione 16: 3-(2-Methoxyphenyl)-6benzoylsydnone imine $(0.295 \mathrm{~g}, 1.00 \mathrm{mmol}), 2 \mathrm{M}$ of LHMDS in THF $(0.75 \mathrm{~mL}, 1.50 \mathrm{mmol})$, 4-tolyl isothiocyanate $(0.328 \mathrm{~g}, 2.20$ $\mathrm{mmol}$ ) and $12 \mathrm{~mL}$ of THF (abs.) were used. Purification was achieved by column chromatography (silica gel, DCM). Yield: $0.161 \mathrm{~g}(36 \%)$ of a violet solid, $\mathrm{mp}: 274{ }^{\circ} \mathrm{C}$ (decomposition). ${ }^{1} \mathrm{H}$ NMR $\left(600 \mathrm{MHz}, \mathrm{CDCl}_{3}\right): \boldsymbol{\delta}=14.36(\mathrm{~s}, 1 \mathrm{H}, 17-\mathrm{H}), 7.42-7.43(\mathrm{~m}$, $\left.2 \mathrm{H}, 7 / 7^{\prime}-\mathrm{H}\right), 7.39-7.41\left(\mathrm{~m}, 2 \mathrm{H}, 13 / 13^{\prime}-\mathrm{H}\right), 7.38-7.40(\mathrm{~m}, 2 \mathrm{H}$, 8/8'H), 7.29-7.31 (m, 3H, 12/12'-H + 23-H), 7.03-7.05 (m, $1 \mathrm{H}$, 21-H), 6.88-6.91 (m, 2H, 20-H + 22-H), $3.94(\mathrm{~s}, 3 \mathrm{H}, 25-\mathrm{H}), 2.48$ (s, 3H, 10-H), 2.46 (s, 3H, 15-H) ppm; ${ }^{13} \mathrm{C}$ NMR $(150 \mathrm{MHz}$, $\mathrm{CDCl}_{3}$ ): $\boldsymbol{\delta}=173.6$ (o, C-4), 170.1 (o, C-2), 147.7 (o, C-19), 140.0 (o, C-14), 139.2 (o, C-9), 134.7 (o, C-5), 132.3 (o, C-11), 131.8 (o, C-6), 131.5 (o, C-18), 130.0 (+, C-13/13'), 129.8 (+, C-8/8'), $126.3\left(+, \mathrm{C}-12 / 12^{\prime}\right), 126.0\left(+, \mathrm{C} 7 / 7^{\prime}\right), 121.5(+, \mathrm{C}-21), 121.5(+$, C-22), 112.1 (+, C-23), $110.5(+$, C-20), 56.1 (+, C-25), $21.6(+$, C-10) 21.6 (+, C-15) ppm; IR (ATR): 3041, 2943, 2842, 1596, $1549,1511,1477,1417,1391,1318,1298,1255,1208,1180$ $1151,1111,1090,1040,1022,986,869,802,782,742,725$, $646,630,576,551,520 \mathrm{~cm}^{-1}$; MS (ESI $\left.30 \mathrm{~V}\right) \mathrm{m} / \mathrm{z}(\%)=469.1$ 
(100) $\left[\mathrm{M}+\mathrm{Na}^{+}\right.$]. HR-ESI-MS: calcd for $\mathrm{C}_{24} \mathrm{H}_{23} \mathrm{~N}_{4} \mathrm{O}_{1} \mathrm{~S}_{2}{ }^{+} 447.1313$. Found 447.1310.

\begin{abstract}
1,3-Di-(4-chlorophenyl)-5-(2-(2-methoxyphenyl)-hydrazono)imidazolidine-2,4-dione 17: 3-(2-Methoxyphenyl)-6benzoylsydnone imine $(0.295 \mathrm{~g}, 1.00 \mathrm{mmol}), 2 \mathrm{M}$ of LHMDS in THF $(0.60 \mathrm{~mL}, 1.20 \mathrm{mmol})$, 4-chlorophenyl-isocyanate $(0.338 \mathrm{~g}$, $2.20 \mathrm{mmol}$ ) and of $12 \mathrm{~mL}$ THF (abs.) were used. Purification was achieved by column chromatography (silica gel, DCM:PE = 10:1) Yield: $0.195 \mathrm{~g}(43 \%)$ of a yellow solid, mp: $259^{\circ} \mathrm{C}$. ${ }^{1} \mathrm{H}$ NMR $(600$ $\mathrm{MHz}^{\mathrm{CDCl}} \mathrm{CD}_{3}: \boldsymbol{\delta}=11.34(\mathrm{~s}, 1 \mathrm{H}, 15-\mathrm{H}), 7.57-7.59(\mathrm{~m}, 2 \mathrm{H}, 12 / 12$ '$\mathrm{H})$, 7.51-7.53 (m, 2H, 8/8'-H), 7.49-7.51 (m, 2H, 11/11'H), 7.48$7.50\left(\mathrm{~m}, 2 \mathrm{H}, 7 / 7^{\prime}-\mathrm{H}\right) 7.27-7.29(\mathrm{~m}, 1 \mathrm{H}, 21-\mathrm{H}), 6.91-6.93(\mathrm{~m}, 2 \mathrm{H}$, $19-\mathrm{H}+20-\mathrm{H}), 6.86-6.87(\mathrm{~m}, 1 \mathrm{H}, 18-\mathrm{H}), 3.90(\mathrm{~s}, 3 \mathrm{H}, 23-\mathrm{H}) \mathrm{ppm}$; ${ }^{13} \mathrm{C}$ NMR $\left(150 \mathrm{MHz}, \mathrm{CDCl}_{3}\right): \boldsymbol{\delta}=155.7$ (o, C-4), 150.0 (o, C-2), 146.4 (o, C-17), 134.5 (o, C-6), 133.5 (o, C-10), 132.3 (o, C-16), 130.8 (o, C-13), 129.6 (+, C-11/11'), 129.4 (+, C-7/7'), 129.2 (o, C-9), 127.5 (+, C-12/12'), 127.2 (+, C8/8'), 125.4 (o, C-5), 122.2 (+, C-19), 121.6 (+, C-20), 112.2 (+, C-21), 110.6 (+, C-18), 55.9 (+, C-23) ppm; IR (ATR): 3275, 3099, 3060, 2942, 2838, 1749, $1704,1594,1523,1493,1401,1248,1215,1175,1138,1091$, 1017, 944, 821, 794, 759, 735, 671, 595, 508, $482 \mathrm{~cm}^{-1}$; MS $\left(\right.$ ESI 30 V) $m / z(\%)=477.0(100)\left[\mathrm{M}_{+} \mathrm{Na}^{+}\right]$. HR-ESI-MS: calcd for $\mathrm{C}_{22} \mathrm{H}_{16} \mathrm{~N}_{4} \mathrm{O}_{3} \mathrm{Cl}_{2} \mathrm{Na}^{+}$477.0497. Found 477.0492.
\end{abstract}

\section{1-(4-Chlorophenyl)-3-(N-(4-methylphenyl)carbamoyl)-4-(4- methylphenyl)-4,5-dihydro-1,2,4-triazol-5-on 18: 3-(4-} Chlorophenyl)-6-benzoylsydnone imine $(0.300 \mathrm{~g}, 1.00 \mathrm{mmol}), 2$ $\mathrm{M}$ of LHMDS in THF $(0.60 \mathrm{~mL}, 1.20 \mathrm{mmol})$, 4-tolyl isocyanate $(0.30 \mathrm{~mL}, 2.40 \mathrm{mmol})$ and $12 \mathrm{~mL}$ of THF (abs.) were used. Purification was achieved by column chromatography (silica gel, DCM, then again PE:EE 3:1). Yield: $0.109 \mathrm{~g} \mathrm{(26 \% )}$ of a white solid, mp: $236{ }^{\circ} \mathrm{C} .{ }^{1} \mathrm{H}$ NMR $\left(600 \mathrm{MHz}, \mathrm{CDCl}_{3}\right): \boldsymbol{\delta}=8.56(\mathrm{~s}, 1 \mathrm{H}$, 16-H), 7.99-8.02 (m, 2H, 7/7'-H), 7.45-7.47 (m, 2H, 18/18'-H) 7.42-7.45 (m, 2H, 8/8'-H), 7.29-7.31 (m, 2H, 12/12'-H), 7.25-7.27 (m, 2H, 11/11'-H), 7.11-7.13 (m, 2H, 19/19'-H), 2.41 (s, 3H, 14$\mathrm{H}), 2.31$ (s, 3H, 21-H) ppm; ${ }^{13} \mathrm{C}$ NMR (150 MHz, $\left.\mathrm{CDCl}_{3}\right): \boldsymbol{\delta}=$ 152.8 (o, C-15), 151.6 (o, C-3), 139.5 (o, C-13), 138.6 (o, C-5), 135.7 (o, C-6), 135.0 (o, C-20), 133.9 (o, C-17'), 131.8 (o, C-9), 130.1 (o, C-10), 129.9 (+, C-12/12'), 129.6 (+, C-19/19'), 129.2 (+, C-8/8'), 126.9 (+, C11/11'), 120.3 (+, C-7/7'), 119.9 (+, C18/18'), 21.3 (+, C-14) 20.9 (+, C-21) ppm; IR (ATR): 3387, 3039 2922, 2859, 1717, 1699, 1595, 1533, 1516, 1490, 1443, 1403, $1370,1298,1238,1176,1090,1010,887,837,806,728,718$, 594, 579, $511 \mathrm{~cm}^{-1}$; MS (ESI $\left.30 \mathrm{~V}\right) \mathrm{m} / z(\%)=441.0(100)$ [M+Na+]. HR-ESI-MS: calcd for $\mathrm{C}_{23} \mathrm{H}_{19} \mathrm{~N}_{4} \mathrm{O}_{2} \mathrm{Cl}_{1} \mathrm{Na}^{+} 441.1094$. Found 441.1096.

\section{1-(4-Chlorophenyl)-3-(N-(4-chlorophenyl)carbamoyl)-4-(4-} chlorophenyl)-4,5-dihydro-1,2,4-triazol-5-on 19: 3-(4Chlorophenyl)-6-benzoylsydnone imine $(0.300 \mathrm{~g}, 1.00 \mathrm{mmol}), 2$ $\mathrm{M}$ of LHMDS in THF $(0.75 \mathrm{~mL}, 1.50 \mathrm{mmol})$, 4-chlorophenyl isocyanate $(0.369 \mathrm{~g}, 2.40 \mathrm{mmol}$ ) and $12 \mathrm{~mL}$ of THF (abs.) were used. Purification was achieved by column chromatography (silica gel, DCM then again PE:EE 3:1). Yield: $0.121 \mathrm{~g}(26 \%)$ of a white solid, $\mathrm{mp}: 270{ }^{\circ} \mathrm{C}$. ${ }^{1} \mathrm{H}$ NMR $\left(600 \mathrm{MHz}, \mathrm{CDCl}_{3}\right): \boldsymbol{\delta}=8.60$ $(\mathrm{s}, 1 \mathrm{H}, 15-\mathrm{H}), 7.98-8.00\left(\mathrm{~m}, 2 \mathrm{H}, 7 / 7^{\prime}-\mathrm{H}\right), 7.53-7.55(\mathrm{~m}, 2 \mathrm{H}$,
17/17'-H) 7.48-7.51 (m, 2H, 12/12'-H), 7.45-7.48 (m, 2H, 12/12'$\mathrm{H})$, 7.33-7.35 (m, 2H, 11/11'-H), 7.30-7.33 (m, 2H, 18/18'-H) ppm; ${ }^{13} \mathrm{C}$ NMR $\left(150 \mathrm{MHz}, \mathrm{CDCl}_{3}\right): \delta=153.0$ (o, C-14), 151.4 (o, C-3), 138.0 (o, C-5), 135.7 (o, C-13), 135.5 (o, C-6), 134.9 (o, C16), 132.4 (o, C-9), 131.2 (o, C-10), 130.7 (o, C-19), 129.7 (+, C12/12'), $129.5\left(+, C-8 / 8^{\prime}\right), 129.4\left(+, C-18 / 18^{\prime}\right), 128.7\left(+, C 11 / 11^{\prime}\right)$, 121.4 (+, C-17/17'), 120.6 (+, C-7/7') ppm; IR (ATR): 3387, 3100, $1731,1703,1593,1532,1489,1398,1372,1302,1240,1180$, 1089, 1002, 889, 842, 824, 789, 727, 601, 567, 500, $442 \mathrm{~cm}^{-1}$

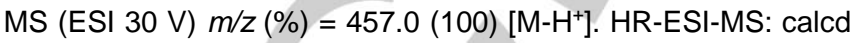
for $\mathrm{C}_{21} \mathrm{H}_{12} \mathrm{~N}_{4} \mathrm{O}_{2} \mathrm{Cl}_{3}-457.0026$. Found 457.0026.

From 1,3-Di-(4-methylphenyl)-5-(2-(4-chlorophenyl)hydrazono)- imidazolidine-2,4-dione (12) to

1-(4-Chlorophenyl)-3-(N-(4-methylphenyl)carbamoyl)-4-(4methylphenyl)- 4,5-dihydro-1,2,4-triazol-5-on 18: Under an inert atmosphere 1,3-di-(4-methylphenyl)-5-(2-(4-chlorophenyl)hydrazono)-imidazolidine-2,4-dione $(0.035 \mathrm{~g}, 0.084 \mathrm{mmol})$ was dissolved in $10 \mathrm{~mL}$ of THF (abs.), then $2 \mathrm{M}$ LHMDS in THF $(0.05$ $\mathrm{mL}, 0.100 \mathrm{mmol}$ ) was added. The mixture was stirred for 10 minutes at $\mathrm{rt}$, afterwards 4-tolyl isocyanate $(0.01 \mathrm{~mL}, 0.092$ $\mathrm{mmol}$ ) was added dropwise. Purification was achieved by column chromatography (silica gel, DCM). Yield: $0.024 \mathrm{~g}(69 \%)$ of a white solid.

\section{Acknowledgements}

Dr. Gerald Dräger, University of Hannover (Germany) is gratefully acknowledged for measuring the high resolution mass spectra. The Deutsche Forschungsgemeinschaft DFG is gratefully acknowledged for financial support.

Keywords: Betaines • Carbenes • Anions • 1,2,4-Triazolones • Imidazolidine-2,4-diones

[1] a) W. D. Ollis, C. A. Ramsden, Adv. Heterocycl. Chem. 1976, 19, 1 122; b) W. D. Ollis, S. P. Stanforth, C. A. Ramsden, Tetrahedron 1985 41, 2239-2329; c) C. A. Ramsden, in P. G. Sammes (ed.), Comprehensive Organic Chemistry, Vol. 4, Pergamon Press, Oxford, 1979, 1171

[2] a) C. A. Ramsden, Tetrahedron 2013, 69, 4146-4159; b) C. A. Ramsden, W. P. Oziminski, Tetrahedron 2014, 70, 7158-7165; c) C. A Ramsden, Progr. Heterocycl. Chem. 2016, 28, 1 - 25.

[3] S. Wiechmann, T. Freese, M. H. H. Drafz, E. G. Hübner, J. C. Namyslo, M. Nieger, A. Schmidt, Chem. Commun. 2014, 50, 11822-11824.

[4] a) T. L. Gilchrist, Science of Synthesis 2004, 13, 109-125; b) D. L. Brown, J. P. Harrity, Tetrahedron 2010, 66, 553-568; c) A. W. Brown, M. Fisher, G. M. Tozer, C. Kanthou, J. P. A. Harrity, J. Med. Chem. 2016, 59, 9473-9488; d) E. Decuypere, L. Plougastel, D. Audisio, F. Taran, Chem. Commun. 2017, 53, 11515-11527; e) A. W. Brown, J. P. A. Harrity, Tetrahedron 2017, 73, 3160-3172; f) T. Wezeman, J. ComasBarcelo, M. Nieger, J. P. A. Harrity, S. Bräse, Org. Biomol. Chem. 2017, 15, 1575-1579.

[5] a) G. Tegginamath, R. R. Kamble, P. P. Kattimani, P. Pramod, S. B. Margankop, Arab. J. Chem. 2016, 9, S306-S312; b) R. Chandrasekhar, M. J. Nanjan, Mini-Rev. Med. Chem. 2012, 12, 1359-1365; c) M.-H. Shih, J.-C. Chen, G.-L. Lin, T.-T. Lin, M.-H. Sun, J. Pharm. Pharmacol. 
2014, 66, 73-83; d) G. Tegginamath, R. R. Kamble, T. Taj, P. P Kattimani, G. Y. Meti, Med. Chem. Res. 2013, 22, 4367-4375.

[6] a) H. Meier, N. Hanold, in Houben-Weyl, Methoden der organischen Chemie, Vol. E 8c (Eds.: K. H. Büchel, J. Falbe, H. Hagemann, M. Hanack, D. Klamann, R. Kreher, H. Kropf, M. Regitz, E. Schaumann), Thieme Verlag, Stuttgart, 1994, p. 403-408; b) P. Brookes, J. Walker, J. Chem. Soc. 1957, 4409-4416; c) H. Kato, M. Hashimoto, M. Ohta, Nippon Kagaku Zasshi 1957, 78, 707

[7] V. G. Yashunskii, L. E. Kholodov, Russ. Chem. Rev. 1980, 49, 28-45.

[8] A. Nasr, A. Winkler, M. Tamm, Coord. Chem. Rev. 2016, 316, 68-124

[9] a) A.-L. Lücke, S. Wiechmann, T. Freese, Z. Guan, A. Schmidt, Z. Naturforsch. 2016, 71b, 643-650; A.-L. Lücke, S. Wiechmann, T. Freese, A. Schmidt, Synlett 2017, 28, 1990-1993.

[10] Review: A. Schmidt, S. Wiechmann, T. Freese, ARKIVOC 2013, i, 424469.

[11] C. A. Ramsden, W. P. Oziminski, J. Org. Chem. 2017, 82, 12485 12491.

[12] A. Smeyanov, J. Adams, E. G. Hübner, A. Schmidt, Tetrahedron 2017, 73, 3106-3111.

[13] Review: A. Schmidt, S. Wiechmann, C. F. Otto, Adv. Heterocycl. Chem 2016, 119, 143-172.

[14] a) M. Liu, J. C. Namyslo, M. Nieger, M. Polamo, A. Schmidt, Beilstein J. Org. Chem. 2016, 12, 2673-2681; b) S. Haindl, J. Xu, T. Freese, E. G. Hübner, A. Schmidt, Tetrahedron 2016, 72, 7906-7911; c) M. Liu, M. Nieger, E. Hübner, A. Schmidt, Chem. Eur. J. 2016, 5416-5424.

[15] I. A. Cherepanov, V. N. Kalinin, Mendeleev Commun. 2000, 10, 181182.

[16] T. Freese, A.-L. Lücke, C. A. S. Schmidt, M. Polamo, M. Nieger, J. C. Namyslo, A. Schmidt, Tetrahedron 2017, 73, 5350-5357.

[17] a) L. E. Kholodov, A. M. Khelem, V. G. Yashunskii, Zh. Org. Khim. 1967, 3, 1870; b) A. Chinone, M. Ohta, Chem. Lett. 1972, 969-970.

[18] a) P. Brookes, J. Walker, J. Chem. Soc. 1957, 4409-4416; b) H. U. Daeniker, J. Druey, Helv. Chim. Acta 1962, 45, 2426-2441; c) L. E. Kholodov, E. V. Borisov, V. G. Yashunskii, Khim. Geterotsikl. Soed. 1968, 702; d) G. S. Puranik, H. Suschitzky, J. Chem. Soc. 1967, 1006 1008.

[19] S. A. Zotova, V. G. Yashunskii, Zhur. Org. Khim. 1967, 3, 1889

[20] H. U. Daeniker, J. Druey, Helv. Chim. Acta 1962, 45, 2441-2462.

[21] Y. Saito, T. Teraji, T. Kamiya, Tetrahedron Lett. 1971, 30, 2893-2896.

[22] V. N. Kalinin, S. N. Lebedev, I. A. Cherepanov, I. A. Godovikov, K. A. Lyssenko, E. Hey-Hawkins, Polyhedron 2009, 28, 2411 - 2417.

[23] I. A. Cherepanov, N. V. Egorova, K. B. Martinovich, V. N. Kalinin, Doklady Chem. 2000, 374, 175

[24] C. Elschenbroich, in Organometallchemie, Teubner Studienbücher Chemie, Wiesbaden, 2003

[25] J. Francos, S. Zaragoza-Calero, C. T. O’Hara, DaltonTrans. 2014, 43, 1408-1412.

[26] W. Bauer, W. R. Winchester, P. V. R. Schleyer, Organometallics 1987, 6, 2371-2379.

[27] L. B. Belykh, Yu. Yu. Titova, A. V. Rokhin, L. N. Belonogova, F. K. Shmidt, Russ. J. Appl. Chem. 2008, 81, 956-964.

[28] I. A. Cherepanov, S. N. Lebedev, A. S. Samarskayalvan, A. Godovikov, Y. V. Nelyubina, V. N. Kalinin, Mendeleev Commun. 2009, 19, 322-323.

[29] W. Desens, T. Werner, Adv. Synth. Catal. 2016, 358, 622-630; b) I. Tommasi, F. Sorrentino, Tetrahedron Lett. 2006, 47, 6453-6456; c) G. de Robillard, C. H. Devillers, D. Kunz, H. Cattey, E. Digard, J. Andrieu Org. Lett. 2013, 15, 4410-4413; d) H. Zhou, W.-Z. Zhang, C.-H. Liu, J.P. Qu, X.-B. Lu, J. Org. Chem. 2008, 73, 8039-8044; e) A. Schmidt, A Beutler, M. Albrecht, F. J. Ramírez, Org. Biomol. Chem. 2008, 6, $287-$ 295; f) B. Bantu, G. Manohar Pawar, K. Wurst, U. Decker, A. M Schmidt, M. R. Buchmeiser, Eur. J. Inorg. Chem. 2009, 1970-1976; g) B. R. van Ausdall, J. L. Glass, K. M. Wiggins, A. M. Aarif, J. Louie, J. Org. Chem. 2009, 74, 7935-7942.

[30] Review: A. Schmidt, Z. Guan, Synthesis 2012, 3251-3268.
[31] a) A. Schmidt, B. Snovydovych, T. Habeck, P. Dröttboom, M. Gjikaj, A Adam, Eur. J. Org. Chem. 2007, 4909-4916; b) A. Schmidt, A. Beutler T. Habeck, T. Mordhorst, B. Snovydovych, Synthesis 2006, 1882-1894.

[32] A. Nagaki, K. Imai, S. Ishiuchi, J-i. Yoshida, Angew. Chem. Int. Ed. 2015, 54, 1914-1918.

[33] a) A. Matsuzawa, S. Takeuchi, K. Sugita, Chem. Asian J. 2016, 11 , 2863-2866; b) V. Pace, L. Castoldi, S. Monticelli, S. Safranek, A. Roller, T. Langer, W. Holzer, Chem . Eur. J. 2015, 21, 18966-18970

[34] a) A. Nagaki, Y. Takahashi, J.-i. Yoshida, Chem. Eur. J. 2014, 20, 7931-7934; b) J. Wu, X. Yang, Z. He, X. Mao, T. A. Hatton, T. Jamison, Angew. Chem. Int. Ed. 2014, 53, 8416-8420.

[35] M. W. Wallasch, G. Y. Vollmer, A. Kafiyatullina, G. Wolmershäuser, P. G. Jones, M. Mang, W. Meyer, H. Sitzmann, Z. Naturforsch. 2009, 64b, 18-24.

[36] a) H. Gotthardt, J. Blum, K. H. Schenk, Chem. Ber. 1986, 119, 1315 1330; b) A. Ohta, F. Okazaki, Y. Yamanoi, M. Maeda, A. Aoyagi, T. Kurihara, G.-L. Pang, Chem. Pharm. Bull. 1995, 43, 705-707; c) T. Kappe, W. Lube, K. Thonhofer, C. Kratky, U. G. Wagner, Heterocycles 1995, 40, 681-689; d) M. Brettreich, M. Bendikov, S. Chaffins, D. F. Perepichka, O. Dautel, H. Duong, R. Helgeson, F. Wudl, Angew. Chem. Int. Ed. 2002, 41, 3688-3691.

[37] G. M. Sheldrick, Acta Crystallogr. 2008, A64, 112-122.

[38] G. M. Sheldrick, Acta Crystallogr. 2015, C71, 3-8.

[39] G. Deguest, A. Devineau, L. Bischoff, C. Fruit, F. Marsais, Org. Lett., 2006, 8, 5889-5892.

[40] K. Rehse, K.-J. Schleifer, T. Ciborski, H. Bohn, Arch. Pharm. 1993, 326 791-797.

[41] H. Wang, Y. Shao, H. Zheng, H. Wang, J. Cheng, X. Wan, Chem. Eur. J. 2015, 21, 18333-18337. 


\section{FULL PAPER}

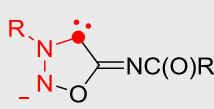<smiles>[R]NC([X])/C(=N\C([R])=O)[R18]1cnon1</smiles>
or

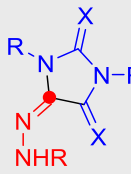

$$
\text { or } \sum_{N}^{N}
$$

Sydnone imine anions combine elements of anionic $\mathrm{N}$-heterocyclic carbenes and mesomeric betaines. Thus, reaction with isocyanates $(X=O)$ or isothiocyanates $(X$ $=S)$ give adducts of the carbene type $\sigma$ orbitals, whereas ring transformations to give imidazolidine-2,4-dithiones, imidazolin-2,4-diones and 1,2,4-triazol-5-ons result from their characteristic $\pi$ architecture of betaines.
Anionic N-heterocyclic carbenes

Tyll Freese, Ana-Luiza Lücke, Jan C. Namyslo, Martin Nieger, and Andreas Schmidt*

Page No. - Page No.

Heterocycle syntheses with anionic N-heterocyclic carbenes. Ring transformations of sydnone imine anions 